\title{
The low-grade Canal de las Montañas Shear Zone and its role in the tectonic emplacement of the Sarmiento Ophiolitic Complex and Late Cretaceous Patagonian Andes orogeny, Chile
}

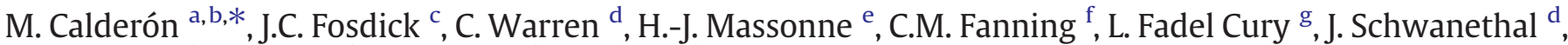 \\ P.E. Fonseca ${ }^{\text {h }}$, G. Galaz $^{\text {b }}$, D. Gaytán ${ }^{\text {b }}$, F. Hervé ${ }^{\text {b,i }}$ \\ a Servicio Nacional de Geología y Minería, Av. Santa María 0104, Santiago, Chile \\ b Departamento de Geología, Universidad de Chile, Casilla 13518, Correo 21, Santiago, Chile \\ ${ }^{c}$ Geological and Environmental Sciences, Stanford University, Stanford, CA 94305, United States \\ d Department of Earth and Environmental Sciences, CEPSAR, The Open University, Walton Hall, Milton Keynes, MK6AA, United Kingdom \\ e Institut für Mineralogie und Kristallchemie, Universität Stuttgart, Azenbergstrasse 18, D-70174, Germany \\ ${ }^{\mathrm{f}}$ Research School of Earth Sciences, The Australian National University, Canberra, Australia 0200 \\ g Departamento de Geologia, Universidade Federal do Paraná, Cep 81531-990, Curitiba, Paraná, Brasil \\ hepartamento e Centro e Geología, FCUL - CeGUL Ed. C6, 2 Piso, Campo Grande, 1700 Lisboa, Portugal \\ i Escuela de Ciencias de la Tierra, Universidad Andrés Bello, Sazie 2315, Santiago, Chile
}

\section{A R T I C L E I N F O}

\section{Article history:}

Received 8 April 2011

Received in revised form 9 November 2011

Accepted 21 December 2011

Available online 29 December 2011

\section{Keywords:}

Patagonian Andes

Sarmiento Ophiolitic Complex

Rocas Verdes basin

Metamorphic sole

Geochronology

Geothermobarometry

\begin{abstract}
A B S T R A C T
The Canal de las Montañas Shear Zone (CMSZ), southern Patagonian Andes (51-52 ${ }^{\circ} \mathrm{S}$ ), is a low-grade mylonite belt generated from felsic ignimbritic, pelitic and basaltic protoliths of the Late Jurassic-Early Cretaceous Rocas Verdes basin. The different types of rock fabrics across the CMSZ are thought to be associated with relatively intermediate and high strain conditions, characterized by the development of a narrow western belt of $\mathrm{S}$ - $\mathrm{C}^{\prime}$-type mylonites and phyllonites interpreted as the metamorphic sole thrust of the Sarmiento Ophiolitic Complex. Highly strained rocks of the CMSZ display a reverse, continent-ward tectonic transport, with a minor dextral component of shearing. Transitional pumpellyite-actinolite and upper greenschist facies metamorphic conditions at ca. 5-6 kbar and $230-260{ }^{\circ} \mathrm{C}$ indicate that the primary shearing event occurred in a subduction zone setting. In-situ ${ }^{40} \mathrm{Ar} /{ }^{39} \mathrm{Ar}$ laserprobe chronology yielded ages of ca. $85 \mathrm{Ma}$ on syntectonic phengite which are interpreted as representing cooling synchronous with mica crystallization during the main compressive deformational event. The 78-81 Ma U-Pb zircon crystallization ages of crosscutting plutonic and hypabyssal rocks and ${ }^{40} \mathrm{Ar} /{ }^{39} \mathrm{Ar}$ amphibole age of ca.79 Ma from lamprophyric dikes within the fold-thrust belt constrain an upper age limit of the ophiolite tectonic emplacement deformation.

(c) 2011 Elsevier B.V. All rights reserved.
\end{abstract}

\section{Introduction}

Most ophiolites, interpreted as fragments of oceanic-like lithosphere tectonically emplaced over continental crust (Anonymous, 1972), have been formed during different stages of the Wilson cycle evolution of ancient oceans, and subsequently incorporated into continental margins through collisional and/or accretionary orogenic events (Dilek, 2003). The oceanic crust that constitutes ophiolites is thought to originate at spreading centers in the middle of the ocean basins, near or behind oceanic island arcs, or in narrow and often marginal intercontinental rift basins. In particular, suprasubduction zone ophiolites, in which mafic igneous rocks were generated from metasomatized mantle sources with oceanic slab-derived components (Pearce et al., 1984), are constituents of most Phanerozoic

\footnotetext{
* Corresponding author at: Servicio Nacional de Geología y Minería, Av. Santa María 0104, Santiago, Chile. Tel.: +56 24825500.

E-mail address: mccaldera@gmail.com (M. Calderón).
}

orogenic belts (Dilek, 2003). These types of ophiolites suggest oceanic crust was generated in subduction rollback cycles during the closing stages of basins prior to terminal continental collisions (Dilek, 2003). On the basis of their emplacement mechanisms, two main prototypes of ophiolites are identified (Beccaluva et al., 2004; Wakabayashi and Dilek, 2003): the Tethyan-ophiolites, that in general display a complete ophiolite pseudostratigraphy with a structurally underlying metamorphic sole of low-pressure amphibolite-facies metamorphic rocks; and the Cordilleran-ophiolites, characterized by incomplete ophiolite pseudostratigraphy with a structurally underlying metamorphic sole of high-pressure blueschist-facies metamorphic rocks.

In the southern Andes and the northern arm of the Scotia Ridge, an orogen-parallel string of Late Jurassic to Early Cretaceous ophiolitic complexes have been tectonically thrust upon the South American margin during ensuing Andean orogenic processes (cf. Dalziel, 1981; Curtis et al., 2010; Stern and de Wit, 2003; Fig. 1). They have been interpreted as the seafloor remnants of the Rocas Verdes basin, a 


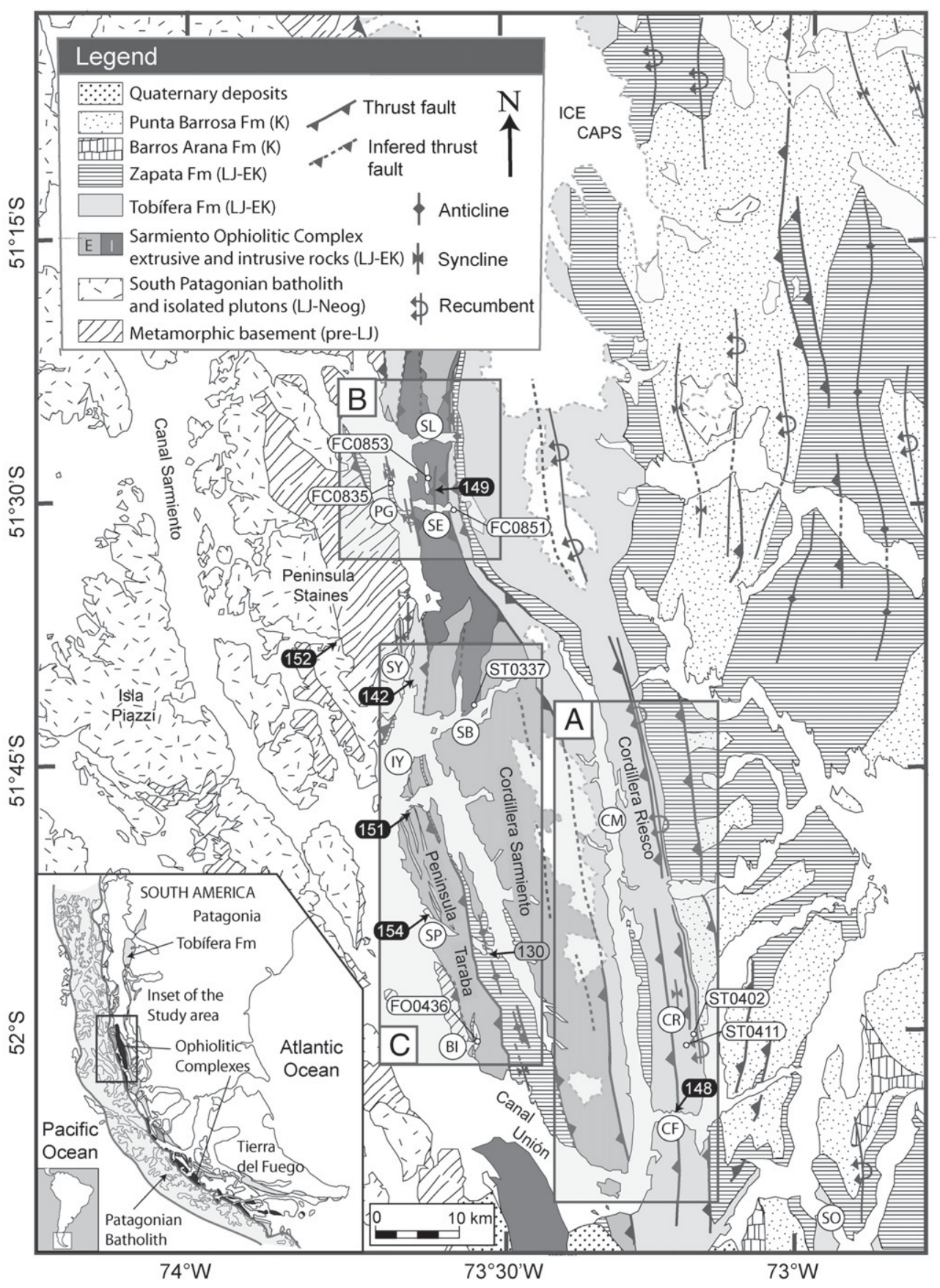

Fig. 1. Geological sketch map of the Cordillera Sarmiento and surrounding areas (modified from Stewart et al., 1971; Allen, 1982; Mapa Geológico de Chile, 2003; Calderón et al., 2007a), with indication of the sampled localities. Black ellipses indicate SHRIMP U-Pb zircon crystallization ages in Ma for main geological units. The age within grey ellipses is the younger age analysed in detrital zircon populations from fine turbidites within the upper member of the Zapata Formation. Abbreviations are: BI: Bahía Intircate; CM: Canal de las Montañas; CR: Cerro Ratón; CF: Caleta Fondeo; IY: Isla Young; PG: Península Garfio; SB: Seno Benavente; SE: Seno Encuentros; SL: Seno Lolos; SP: Seno Profundo; SY: Seno Yussef.

quasi-oceanic back-arc basin developed over an Atlanticward dipping subduction zone (in present-day geographic coordinates) (Dalziel, 1981; Stern and de Wit, 2003; Suárez and Pettigrew, 1976). The Rocas Verdes basin inception occurred in a rift predecessor located near the western continental margin (Calderón et al., 2007a; Hervé and Fanning, 2003) associated with the early tectonic fragmentation of Gondwana in southern South America and Antarctic Peninsula (Bruhn et al., 1978; Pankhurst et al., 2000). The Rocas Verdes basin closure and succeeding ophiolite obduction and collision between the drifted microplate and the cratonic margin, have been associated with the main phase of the Andean orogenesis in southern South America (Dalziel, 1981, 1986; Klepeis et al., 2010; Kohn et al., 1995; Maloney et al., 2011). As such, the structure and petrology of the
Rocas Verdes ophiolitic complexes and related rocks bear critical information on the history and geodynamic setting of oceanic backarc basin evolution adding constraints on reconstruction of global changes in plate motions and interactions in the southern hemisphere.

Recent studies of the westernmost structures in the Magallanes fold-thrust belt as well as petrological and geochemical considerations of the Sarmiento Ophiolitic Complex (SOC, 50-52 ${ }^{\circ} \mathrm{S}$ latitude ; Allen, 1982; Calderón et al., 2007a; Fildani and Hessler, 2005; Fosdick et al., 2011; Galaz et al., 2005; Hervé et al., 2007a; Wilson, 1991), suggest that tectonic evolution of the Rocas Verdes basin played an important role in early Andean crustal shortening. However, the timing, kinematics and geodynamic setting of ophiolite tectonic 
emplacement remain poorly constrained. Previous studies on the deformation and metamorphic history of the SOC have recognized and briefly alluded to the existence of a discontinuous mylonite band over $300 \mathrm{~km}$ long that bounds the present outcrops of the SOC to the east (Allen, 1982; Calderón et al., 2005; Galaz et al., 2005; Hervé et al., 2007a; Fig. 1). Additional discontinuous outcrops of mylonitized rocks are also found near the western boundary of the SOC, motivating further inquiry into their origin and potential role in ophiolite emplacement. In this contribution, we present new lithologic, structural and kinematic characteristics of mylonites developed in this newly termed Canal de las Montañas Shear Zone. These results, together with pressure-temperature calculations and a precise geochronological framework indicate that highly strained rocks within the Canal de las Montañas Shear Zone represent the sole thrust of ophiolitic complexes that record considerable uplift and shortening in the early Late Cretaceous regional tectonic development of the Patagonian Andes.

\section{Regional geology}

The Late Mesozoic Rocas Verdes basin (Dalziel, 1981; Dalziel and Cortés, 1972; Dalziel et al., 1974; Katz, 1964; Stern and de Wit, 2003; Storey and Mair, 1982; Suárez and Pettigrew, 1976), interpreted from discontinuous and incomplete ophiolitic complexes and hemipelagic sedimentary successions exposed along the Patagonian and Fuegian Andes, Pacific margin of southern South America, and in the island of South Georgia ( $\left.51^{\circ}-55^{\circ} S\right)$, is characterized by the development of a mafic oceanic-like floor. The Rocas Verdes ophiolites (Stern and de Wit, 2003) are considered to have formed during Late Jurassic times, based on $\mathrm{U}-\mathrm{Pb}$ zircon crystallization ages in plagiogranites of the SOC in the southern Patagonian Andes (Calderón et al., 2007a) and of the Larsen Harbour ophiolitic complex in the island of South Georgia (Mukasa and Dalziel, 1996). The early magmatic ophiolitic components comprise Late Jurassic bimodal suite associations (SOC; Calderón et al., 2007a; Saunders et al., 1979), in which mafic rocks show characteristic elemental composition of enriched mid-ocean ridge basaltic magmas generated from metasomatized mantle sources that was affected by slab dehydration processes in a suprasubduction environment (Calderón et al., 2007b). Bimodal magmatism in the SOC was coeval with silicic explosive volcanism and emplacement of Jurassic granitic plutons of the South Patagonian Batholith, with a significant component of crustal contamination (Calderón et al., 2007b; Hervé et al., 2007b). Late Cretaceous ophiolitic complexes comprise mainly mafic igneous suites in which basalts and gabbroic rocks exhibit tholeiitic affinities (Tortuga Ophiolitic Complex; Avendaño et al., 2008; Saunders et al., 1979; Stern 1979) and characteristic mid-ocean-ridge type chemical and isotopic signatures (Stern, 1991). Compositional differences have been attributed to mantle source variations during the progressive lithospheric thinning in the back-arc region that culminated with the development of the oceanic-type spreading systems (cf. de Wit and Stern, 1981; Stern and de Wit, 2003).

The SOC, which is the northernmost mafic and bimodal seafloor remnant of the Rocas Verdes basin, forms a NNW-SSE elongated lenticular body, $200 \mathrm{~km}$ long by $30 \mathrm{~km}$ wide (Fig. 1). In outcrops, this tectonic unit is delimited to the west by the Late Jurassic to Neogene composite calc-alkaline South Patagonian batholith (Hervé et al., 2007b) and Paleozoic metasedimentary basement rocks (Forsythe and Allen, 1980; Hervé et al., 2003). To the east, the SOC is structurally bound by the Canal de las Montañas Shear Zone, which is the focus of this study. The SOC is composed of massive gabbros, rare plagiogranites, sheeted dikes, and a $2 \mathrm{~km}$-thick extrusive unit composed of pillowed basalts and pillow breccias with intercalations of radiolariabearing cherts and siltstones (Allen, 1982; Dalziel et al., 1974; Stern and de Wit, 2003; Stewart et al., 1971). Between Seno Lolos and Seno Encuentros (Fig. 1), the ophiolitic complex consists of fine to medium grained Jurassic granophyres which are intruded by successive $\mathrm{N}-\mathrm{S}$ trending mafic dikes, dolerite sills and late-stage plagiogranites dated at ca. $149 \mathrm{Ma}$ (Calderón et al., 2007a). Bimodal associations of intrusive and extrusive rocks are interpreted to have formed during the early rifting phase of the Rocas Verdes basin development (Calderón et al., 2007a, 2007b; Stern and de Wit, 2003).

The Middle to Late Jurassic Chon Aike siliceous Large Igneous Province in this western part of South America is represented by the Tobífera Formation (Pankhurst et al., 2000). Geochronologic analysis of the Tobífera Formation in the nearby Sarmiento and Riesco Cordilleras has yielded zircon U-Pb SHRIMP ages of ca.152-142 Ma (Calderón et al., 2007a; Hervé et al., 2007b), and thus was deposited coevally and subsequent to the ophiolitic magmatism. At Seno Yussef (Fig. 1), the Upper Cretaceous (ca. $142 \mathrm{Ma}$ ) silicic tuffs of the Tobífera Formation unconformably overlie the Late Paleozoic low-grade metamorphic rocks of the Staines Complex (Calderón et al., 2007a; Forsythe and Allen, 1980; Hervé et al. 2003). The basal member of this unit comprises a monolithic breccia with centimeter- to metersized boulders of polydeformed metamorphic rocks, overlain by sandstones, mudstones and conglomerates, pyroclastic flow deposits and rhyolitic lava flows (Allen, 1982). To the east of the SOC, the metamorphic basement is only barely exposed at Seno Obstrucción (SE of the area in Fig. 1). There, the base of the Tobifera Formation consists of megabreccia with clasts of metasedimentary rocks that is interpreted as a syn-rift clastic deposit. The Tobífera Formation comprises meter- to decameter-thick intercalations of fossiliferous siltstones indicating that part of this formation was deposited under submarine conditions (Allen, 1982; Wilson, 1991).

The sedimentary infill of the Rocas Verdes basin in the study area is represented by successions of hemipelagic rocks of the Zapata Formation, deposited on top of and intercalated with basalts and/or felsic volcaniclastic rocks. It consists of a fossiliferous Tithonian to Neocomian (Fuenzalida and Covacevich, 1988) succession of siltstones and mudstones which constitutes a composite thickness of more than $1000 \mathrm{~m}$. The upper member of the Zapata Formation also contains fine-grained turbidite sandstones (Allen, 1982; Fuenzalida and Covacevich, 1988) with detrital zircon components indicating a maximum Hauterivian age of sedimentation (Calderón et al., 2007a).

To the east of the Canal de las Montañas the upper member of the Zapata Formation extends eastward onto the Cretaceous continental platform (Fildani and Hessler, 2005; Wilson, 1991) and interfingers with the Lower Cretaceous Barros Arana Formation (Prieto, 1994; Stern et al., 1991). The Barros Arana Formation consists of a succession of spilitized clinopyroxene- and amphibole-bearing basalts and mafic dikes, and volcaniclastic breccias (Fig. 1). The Barros Arana basalts are interpreted as mafic members of the mildly alkaline shoshonitic rock suite of subduction-related arcs (Anguita, 2010; Ramírez, 2006; Stern et al., 1991) and is thought to have formed before the initiation of the closure, deformation, and uplift of the Rocas Verdes basin in the late or post-Albian (Stern et al., 1991).

The initiation of Andean orogenic deformation in the area, which induced the closure of the Rocas Verdes basin and subsequent emplacement of the ophiolite blocks to the east, generated flexural loading and formation of the Magallanes foreland basin (Biddle et al., 1986; Natland et al., 1974; Wilson, 1991). Incipient foreland basin sedimentation, and by inference early stages of thrusting in the hinterland, began as early as Cenomanian time (Fosdick et al., 2011), with a well-developed retroarc thrust belt developed by the Turonian (Fildani et al., 2003).

\section{Methods}

\subsection{Petrography}

Detailed field observations were made in selected outcrops distributed along the Canal de las Montañas structural lineament, as shown in Figs. 2-3. The petrographic study consisted of microstructural analysis 

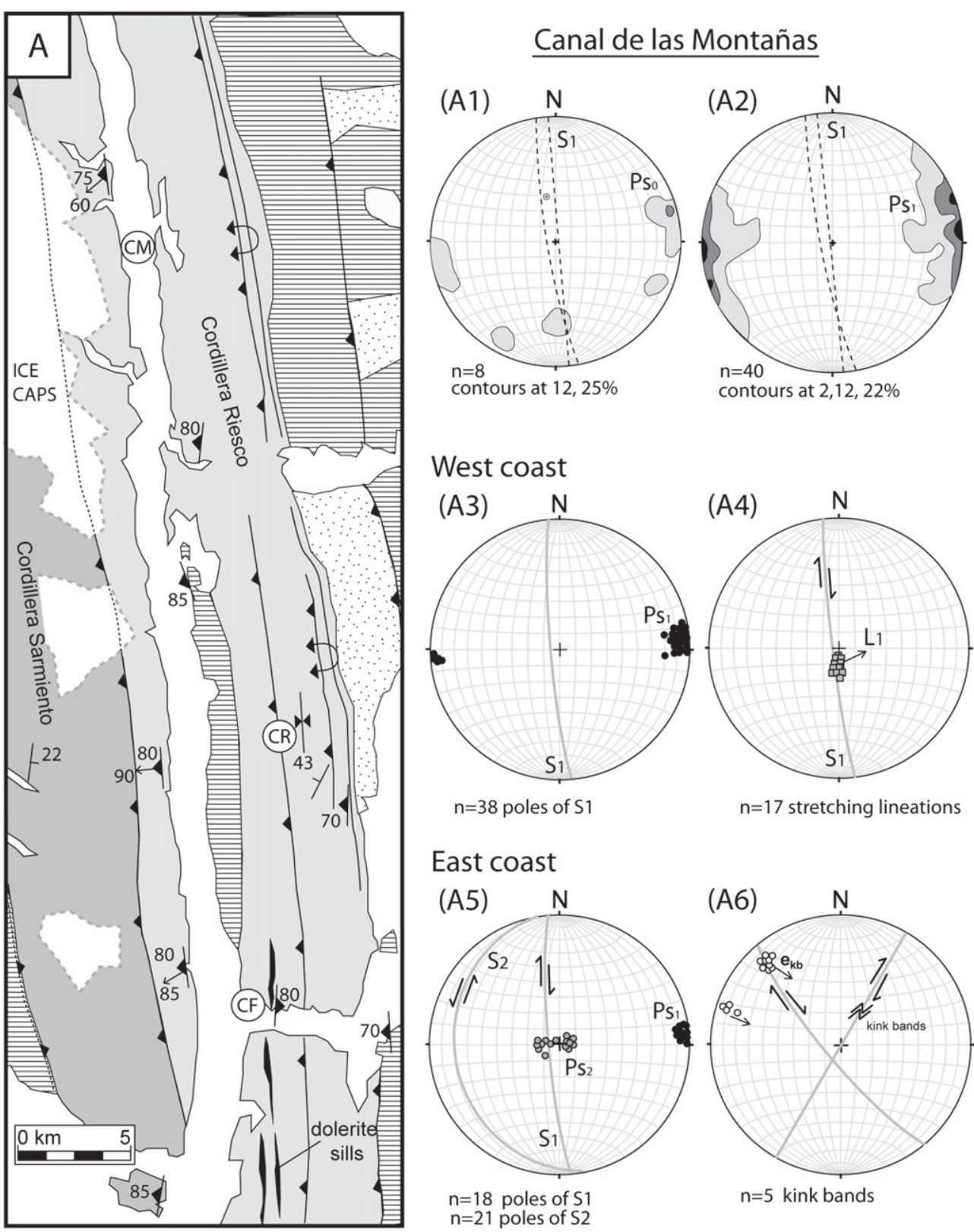

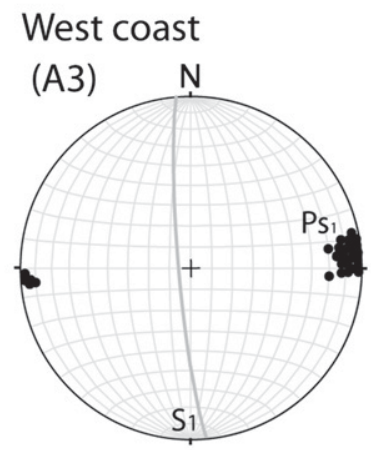

$\mathrm{n}=38$ poles of $\mathrm{S} 1$

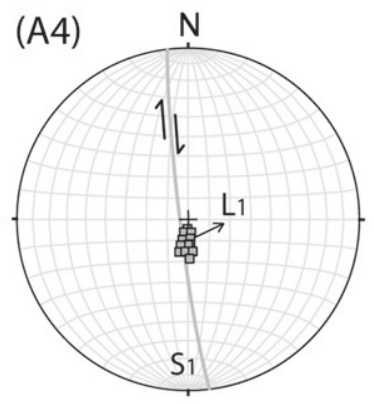

$\mathrm{n}=17$ stretching lineations

\section{East coast}

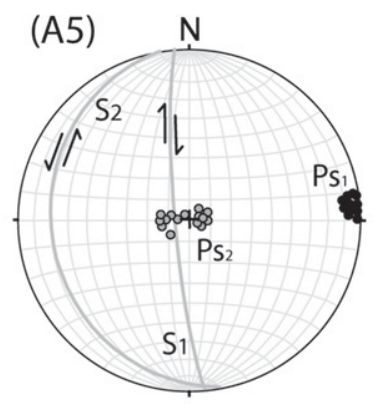

$\mathrm{n}=18$ poles of $\mathrm{S} 1$ $\mathrm{n}=21$ poles of $\mathrm{S} 2$

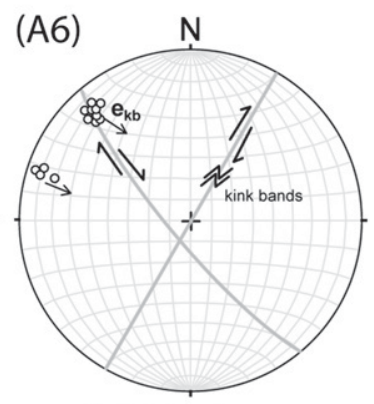

$\mathrm{n}=5$ kink bands

Fig. 2. Simplified map of main structures (stratification, foliation, and lineation) measured along both shores of the Canal de las Montañas. Lower hemisphere, equal area stereographic projections showing: poles of general stratification $\left(S_{0}\right)$ and main foliation $\left(S_{1}\right)$ (A1, A2; data from Allen, 1982); poles and mean strike and dip of main $S_{1}$ foliation and stretching lineation $\left(L_{1}\right)$ showing top-to-the-east sense of shear with a dextral component $(A 3, A 4)$; poles of $S_{1}$ foliation and $S_{2}$ crenulation cleavage with sinistral component (A5); poles of kink bands and fold pattern related with late brittle dextral deformation (A6).

of oriented samples collected in at least 40 localities, with 20 oriented thin-sections to determine shear sense. Microstructural analysis of rock thin-sections allowed us to identify and interpret significant textures and mineral associations, as described below.

\subsection{Electron microprobe and X-ray fluorescence analyses}

Chemical compositions of minerals were obtained on selected samples using a CAMECA SX100 electron microprobe with 5 wavelengthdispersive spectrometers at Universität Stuttgart, Germany. Operating conditions were an acceleration voltage of $15 \mathrm{kV}$, a beam current of $15 \mathrm{nA}$, a beam size of 7-10 $\mu \mathrm{m}$ or a focussed beam (for very small crystals), and 20 seconds counting time on the peak and on the background for each element. The standards used were natural wollastonite ( $\mathrm{Si}$, $\mathrm{Ca})$, natural orthoclase $(\mathrm{K})$, natural albite $(\mathrm{Na})$, natural rhodonite
(Mn), synthetic $\mathrm{Cr}_{2} \mathrm{O}_{3}(\mathrm{Cr})$, synthetic $\mathrm{TiO}_{2}$ (Ti), natural hematite (Fe), natural baryte ( $\mathrm{Ba})$, synthetic $\mathrm{MgO}(\mathrm{Mg})$, synthetic $\mathrm{Al}_{2} \mathrm{O}_{3}(\mathrm{Al})$ and synthetic $\mathrm{NiO}(\mathrm{Ni})$. The PaP correction procedure provided by Cameca was applied. Acquired data are presented in Table 1. The major elements bulk chemical composition of rock samples, required for the calculation of P-T pseudosections, was determined with a PHILIPS PW 2400 X-ray fluorescence (XRF) spectrometer at Universität Stuttgart using glass discs prepared from rock powder and Spectromelt ${ }$.

\section{3. ${ }^{40} \mathrm{Ar} /{ }^{39} \mathrm{Ar}$ analyses}

Samples were analyzed in the Open University ${ }^{40} \mathrm{Ar} /{ }^{39} \mathrm{Ar}$ Laboratory. Polished thick sections of sample STO402 were broken into $5 \times 5 \mathrm{~mm}^{2}$ squares and washed in acetone and distilled water before packing into foil packets. Amphibole separates from samples ST0411 


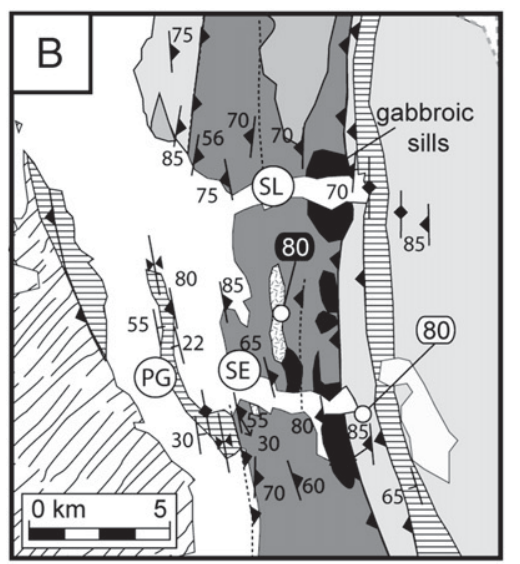

\section{Seno Lolos y Seno Encuentros}

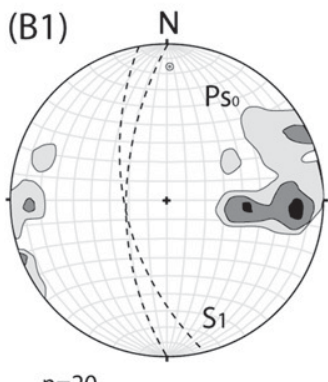

contours at $5,10,25 \%$

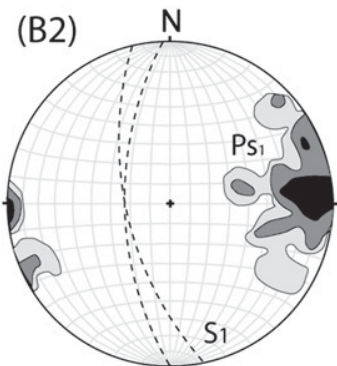

$\mathrm{n}=26$

contours at $4,8,12 \%$

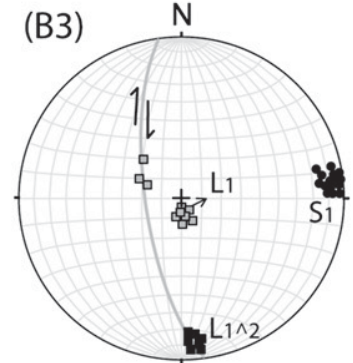

$\mathrm{n}=17$ poles of $\mathrm{S} 1$

$\mathrm{n}=12$ stretching lineation $\mathrm{n}=7$ intersection lineation
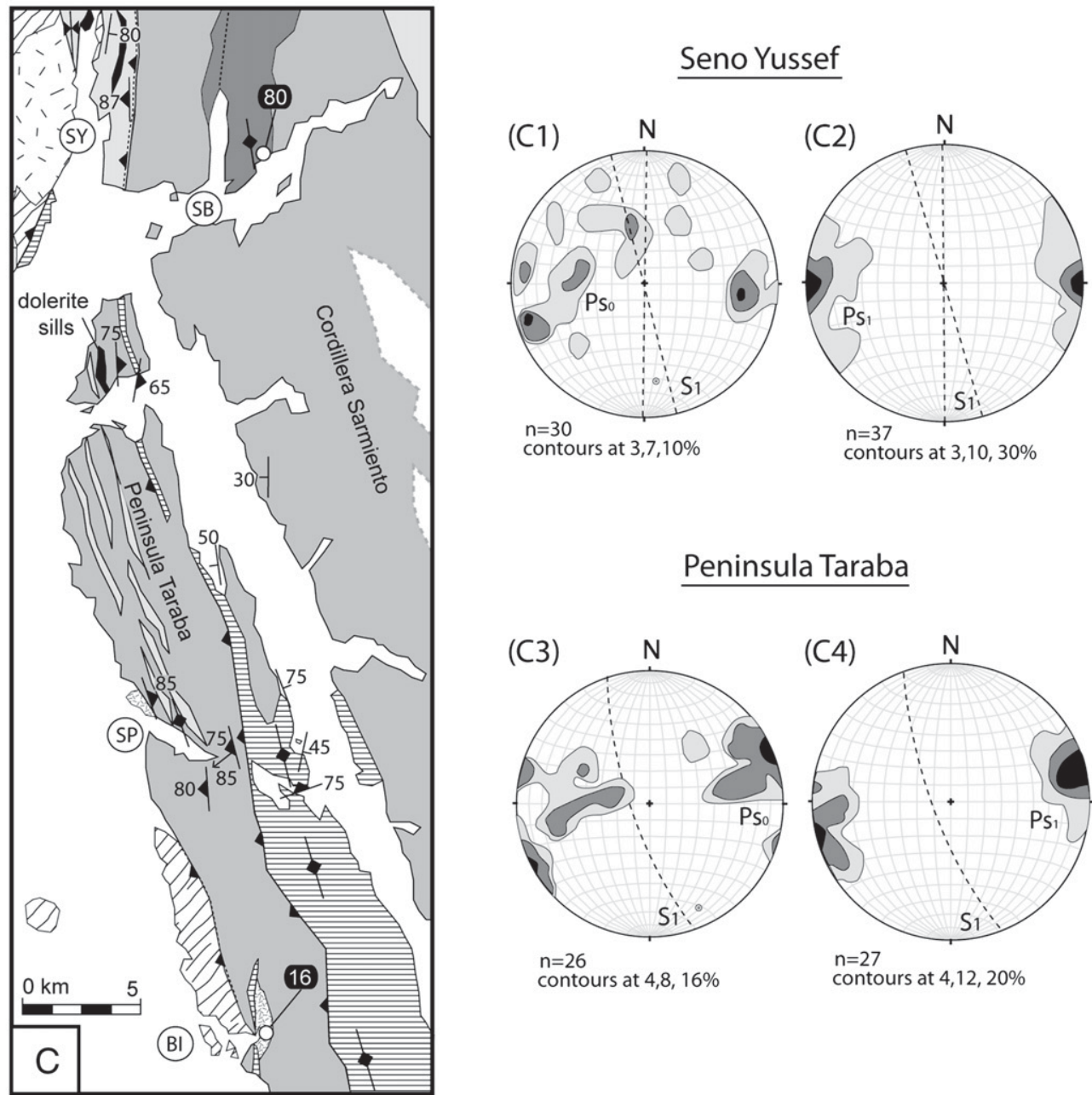

\section{Peninsula Taraba}

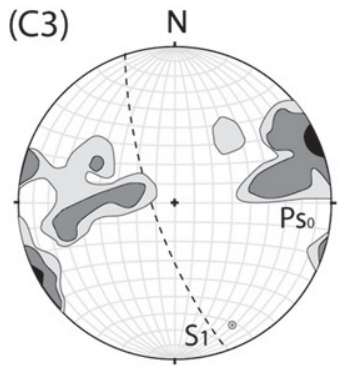

$\mathrm{n}=26$

contours at $4,8,16 \%$

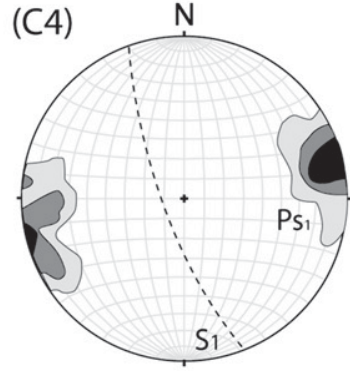

$\mathrm{n}=27$

contours at $4,12,20 \%$

Fig. 3. Simplified map of main structures (stratification, foliation, and lineation) measured at Seno Lolos, Seno Encuentros, Seno Yussef and Peninsula Taraba. Lower hemisphere, equal area stereographic projections showing: poles of general stratification $\left(S_{0}\right)$ and main foliation $\left(S_{1}\right)\left(B 1, B 2 ;\right.$ data from Allen, 1982) and poles of $S_{1}$ and stretching lineations $\left(\mathrm{L}_{1}\right)$ showing top-to-the-east sense of shear with a dextral component with indication of the intersection lineation between $\mathrm{S}_{1}$ and the crenulation cleavage $\mathrm{S}_{2}$ (C3); poles of general stratification $\left(\mathrm{S}_{0}\right)$ and main foliation $\left(\mathrm{S}_{1}\right)(\mathrm{C} 1, \mathrm{C} 2, \mathrm{C} 3, \mathrm{C} 4$; data from Allen, 1982).

and FC0835 were picked under a binocular microscope and about $25 \mathrm{mg}$ of each sample was washed in distilled water and acetone before packing into foil packets. The samples were irradiated at McMaster University in Canada. Mica mats in ST0402 were analysed by spot-dating using an SPI SP25C $1090 \mathrm{~nm}$ laser focussed through a Leica microscope, coupled to an automated extraction system and a $\mathrm{Nu}$ Noblesse mass spectrometer. The amphibole separates were step-heated using a Spectron SL902T $1064 \mathrm{~nm}$ laser coupled to an automated extraction system and a MAP 215-50 mass spectrometer. Neutron fluence was monitored using the GA1550 biotite standard with an age of $98.79 \pm 0.54 \mathrm{Ma}$ (Renne, et al., 1998). J values were calculated by linear interpolation between two bracketing standards (and given in Table 2); a standard was included between every 8 and 10 samples in the irradiation tube. Results were corrected for blanks, ${ }^{37} \mathrm{Ar}$ decay and neutron-induced interference reactions. Typical blank measurements are included for each sample and sample run in 


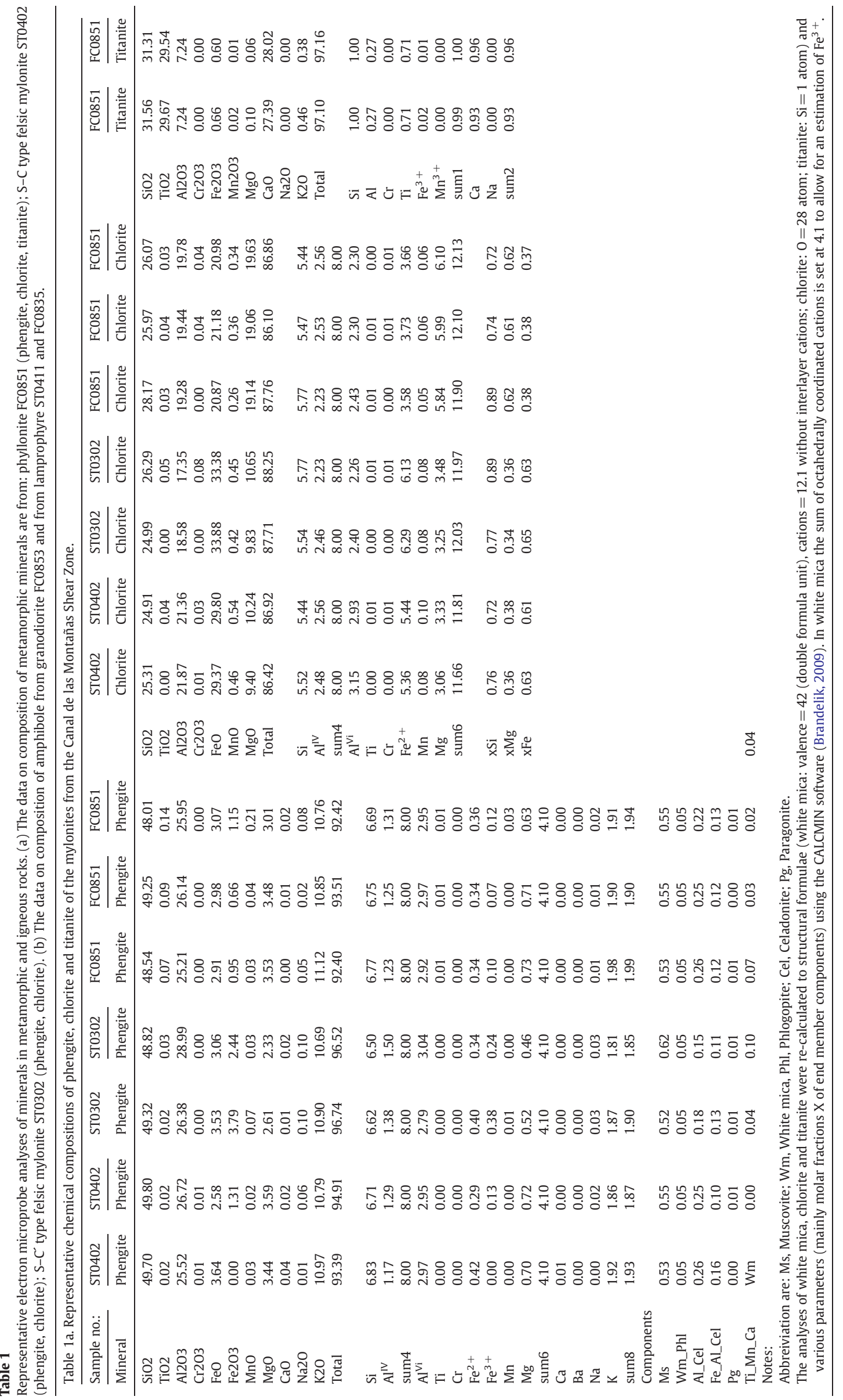




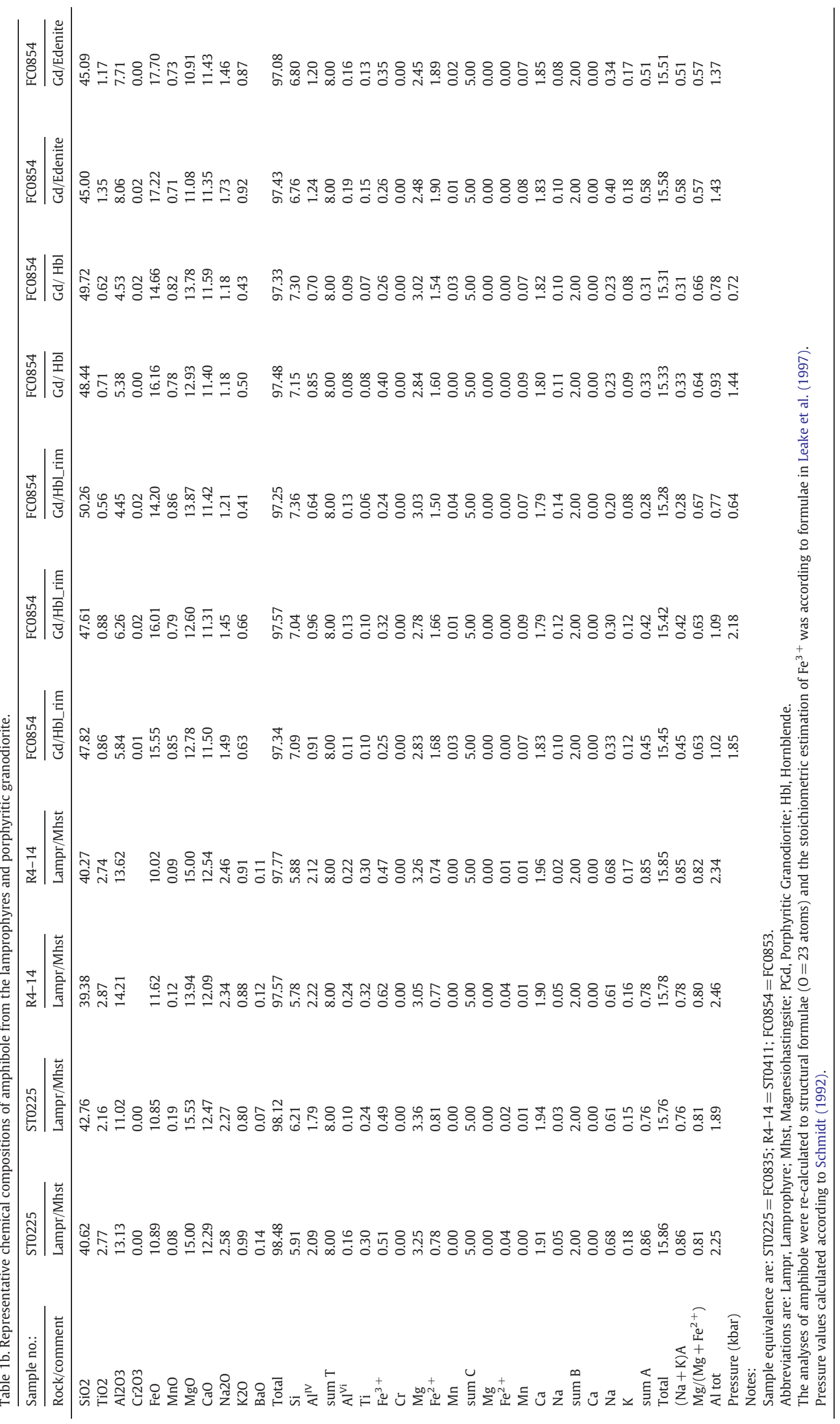


Table 2

Results of ${ }^{40} \mathrm{Ar} /{ }^{39} \mathrm{Ar}$ in situ dating of phengite from S-C type felsic mylonite ST0402 and stepwise heating of magnesiohastingsite from lamprophyre samples ST0411 and FC0835.

Table 2a. Detailed ${ }^{40} \mathrm{Ar} /{ }^{39} \mathrm{Ar}$ analytical data for phengite from mylonite sample ST0402

J value: $0.01 \pm 5 \mathrm{E}-05$

\begin{tabular}{|c|c|c|c|c|c|c|c|c|c|c|c|c|c|c|}
\hline Comment & ${ }^{40} \mathrm{Ar}$ & $\pm(1 \sigma)$ & ${ }^{39} \mathrm{Ar}$ & $\pm(1 \sigma)$ & ${ }^{38} \mathrm{Ar}$ & $\pm(1 \sigma)$ & ${ }^{37} \mathrm{Ar}$ & $\pm(1 \sigma)$ & ${ }^{36} \mathrm{Ar}$ & $\pm(1 \sigma)$ & ${ }^{40} \mathrm{Ar}^{*} /{ }^{39} \mathrm{Ar}$ & $\pm(1 \sigma)$ & Age (Ma) & $\pm(1 \sigma)$ \\
\hline spot 1 & 122489 & 1169 & 28575 & 40.4 & 2.7 & 0.5 & 267 & 260 & 21.3 & 4.0 & 4.07 & 0.058 & 82.96 & 1.22 \\
\hline spot 2 & 223287 & 1190 & 46501 & 92.1 & 3.7 & 1.1 & 1334 & 260 & 44.0 & 4.0 & 4.52 & 0.037 & 92.02 & 0.83 \\
\hline spot 3 & 265713 & 1178 & 37802 & 40.4 & 6.8 & 1.1 & 2180 & 260 & 136.8 & 4.0 & 5.96 & 0.045 & 120.31 & 1.00 \\
\hline spot 4 & 411648 & 1207 & 88455 & 134.5 & 7.8 & 1.1 & 579 & 260 & 62.2 & 4.0 & 4.45 & 0.020 & 90.50 & 0.55 \\
\hline spot 5 & 128686 & 1167 & 29470 & 36.3 & 3.7 & 0.5 & 289 & 260 & 27.3 & 4.0 & 4.09 & 0.056 & 83.49 & 1.18 \\
\hline spot 6 & 283584 & 1188 & 59851 & 100.4 & 3.7 & 1.1 & 1069 & 260 & 67.1 & 4.0 & 4.41 & 0.029 & 89.73 & 0.69 \\
\hline spot 7 & 460289 & 305 & 46379 & 49.7 & 7.8 & 1.4 & 965 & 261 & 148.7 & 1.0 & 8.98 & 0.013 & 178.28 & 0.78 \\
\hline spot 8 & 151166 & 228 & 33859 & 38.3 & 5.8 & 1.4 & 724 & 261 & 19.8 & 1.0 & 4.29 & 0.012 & 87.44 & 0.44 \\
\hline spot 9 & 408132 & 298 & 55969 & 51.7 & 5.8 & 1.4 & 2937 & 261 & 66.2 & 1.0 & 6.94 & 0.010 & 139.40 & 0.61 \\
\hline spot 10 & 580568 & 353 & 136942 & 78.6 & 4.8 & 2.3 & 1570 & 261 & 42.6 & 1.0 & 4.15 & 0.004 & 84.57 & 0.37 \\
\hline spot 11 & 995806 & 497 & 98297 & 60.0 & 6.8 & 2.3 & 1329 & 261 & 259.6 & 2.0 & 9.35 & 0.010 & 185.33 & 0.78 \\
\hline Av. Blank 1-5 & 5711.0 & 19.3 & 64.7 & 1.3 & 7.3 & 1.0 & 306.0 & 2.3 & 24.7 & 1.0 & & & & \\
\hline Av Blank 6-10 & 4137.5 & 12.3 & 57.0 & 1.3 & 7.8 & 1.0 & 290.8 & 2.8 & 18.0 & 0.5 & & & & \\
\hline
\end{tabular}

Table 2b. Detailed ${ }^{40} \mathrm{Ar} /{ }^{39} \mathrm{Ar}$ analytical data for magnesiohastingsite from lamprophyre sample ST0411

\begin{tabular}{|c|c|c|c|c|c|c|c|c|c|c|c|c|c|c|c|}
\hline \multicolumn{16}{|c|}{ J value: $0.0127 \pm 6.35 \mathrm{E}-05$} \\
\hline Comment & ${ }^{40} \mathrm{Ar}$ & $\pm(1 \sigma)$ & ${ }^{39} \mathrm{Ar}$ & $\pm(1 \sigma)$ & ${ }^{38} \mathrm{Ar}$ & $\pm(1 \sigma)$ & ${ }^{37} \mathrm{Ar}$ & $\pm(1 \sigma)$ & ${ }^{36} \mathrm{Ar}$ & $\pm(1 \sigma)$ & ${ }^{39} \mathrm{Ar}$ & $\begin{array}{l}{ }^{40} \mathrm{Ar}^{*} / \\
{ }^{39} \mathrm{Ar}\end{array}$ & $\pm(1 \sigma)$ & $\begin{array}{l}\text { Age } \\
\text { (Ma) }\end{array}$ & $\pm(1 \sigma)$ \\
\hline step 1 & 0.035 & 0.00019 & 0.0007 & 0.00004 & 0.00000 & 0.00003 & 0.002 & 0.00234 & 0.00005 & 0.00002 & 0.1 & 27.58 & 9.75 & 542.39 & 165.62 \\
\hline step 2 & 0.181 & 0.00061 & 0.0086 & 0.00005 & 0.00025 & 0.00003 & 0.021 & 0.00234 & 0.00043 & 0.00002 & 1.1 & 6.32 & 0.77 & 139.48 & 16.40 \\
\hline step 3 & 0.523 & 0.00055 & 0.0641 & 0.00006 & 0.00137 & 0.00003 & 0.320 & 0.00234 & 0.00093 & 0.00002 & 8.4 & 3.87 & 0.10 & 86.72 & 2.29 \\
\hline step 4 & 0.394 & 0.00079 & 0.0932 & 0.00026 & 0.00161 & 0.00003 & 0.555 & 0.00234 & 0.00024 & 0.00003 & 19.1 & 3.47 & 0.09 & 77.99 & 2.02 \\
\hline step 5 & 0.537 & 0.00036 & 0.1370 & 0.00017 & 0.00230 & 0.00004 & 0.825 & 0.00234 & 0.00017 & 0.00002 & 34.8 & 3.56 & 0.05 & 79.89 & 1.13 \\
\hline step 6 & 0.376 & 0.00045 & 0.0995 & 0.00015 & 0.00169 & 0.00002 & 0.595 & 0.00323 & 0.00009 & 0.00002 & 46.1 & 3.51 & 0.07 & 78.67 & 1.59 \\
\hline step 7 & 0.582 & 0.00081 & 0.1445 & 0.00017 & 0.00227 & 0.00003 & 0.866 & 0.00323 & 0.00025 & 0.00002 & 62.7 & 3.52 & 0.03 & 78.89 & 0.83 \\
\hline step 8 & 0.615 & 0.00113 & 0.1708 & 0.00028 & 0.00274 & 0.00004 & 1.071 & 0.00323 & 0.00014 & 0.00002 & 82.2 & 3.37 & 0.03 & 75.60 & 0.73 \\
\hline step 9 & 0.545 & 0.00032 & 0.1551 & 0.00039 & 0.00268 & 0.00003 & 0.957 & 0.00323 & 0.00010 & 0.00002 & 100.0 & 3.33 & 0.03 & 74.83 & 0.78 \\
\hline $\begin{array}{l}\text { Av. Blank } \\
1-5\end{array}$ & 0.0012 & 0.00004 & 0.00004 & 0.00001 & 0.00003 & 0.00001 & 0.00057 & 0.00001 & 0.00004 & 0.00001 & & & & & \\
\hline $\begin{array}{l}\text { Av. Blank } \\
\text { 6-9 }\end{array}$ & 0.0013 & 0.00004 & 0.00004 & 0.00001 & 0.00001 & 0.00001 & 0.00065 & 0.00002 & 0.00004 & 0.00001 & & & & & \\
\hline \multicolumn{16}{|c|}{ Table 2c. Detailed ${ }^{40} \mathrm{Ar} /{ }^{39} \mathrm{Ar}$ analytical data for magnesiohastingsite from lamprophyre sample FC0835 } \\
\hline Comment & ${ }^{40} \mathrm{Ar}$ & $\pm(1 \sigma)$ & ${ }^{39} \mathrm{Ar}$ & $\pm(1 \sigma)$ & ${ }^{38} \mathrm{Ar}$ & $\pm(1 \sigma)$ & ${ }^{37} \mathrm{Ar}$ & $\pm(1 \sigma)$ & ${ }^{36} \mathrm{Ar}$ & $\pm(1 \sigma)$ & $\%^{39} \mathrm{Ar}$ & $\begin{array}{l}{ }^{40} \mathrm{Ar}^{*} / \\
{ }^{39} \mathrm{Ar}\end{array}$ & $\pm(1 \sigma)$ & $\begin{array}{l}\text { Age } \\
\text { (Ma) }\end{array}$ & $\pm(1 \sigma)$ \\
\hline step 1 & 0.046 & 0.00033 & 0.0004 & 0.00006 & 0.00000 & 0.00003 & 0.00032 & 0.00114 & 0.00010 & 0.00002 & 0.0 & 43.62 & 19.25 & 797.83 & 284.59 \\
\hline step 2 & 0.158 & 0.00030 & 0.0020 & 0.00006 & 0.00016 & 0.00003 & 0.01423 & 0.00114 & 0.00026 & 0.00002 & 0.2 & 40.71 & 3.43 & 754.24 & 52.11 \\
\hline step 3 & 0.320 & 0.00061 & 0.0063 & 0.00006 & 0.00023 & 0.00003 & 0.05557 & 0.00114 & 0.00056 & 0.00002 & 0.9 & 24.78 & 1.06 & 495.27 & 18.62 \\
\hline step 4 & 0.400 & 0.00038 & 0.0239 & 0.00016 & 0.00049 & 0.00003 & 0.17147 & 0.00114 & 0.00049 & 0.00002 & 3.3 & 10.71 & 0.28 & 230.83 & 5.71 \\
\hline step 5 & 0.386 & 0.00042 & 0.0469 & 0.00009 & 0.00097 & 0.00003 & 0.28838 & 0.00114 & 0.00037 & 0.00002 & 8.0 & 5.93 & 0.14 & 131.51 & 3.00 \\
\hline step 6 & 0.941 & 0.00144 & 0.1117 & 0.00046 & 0.00218 & 0.00004 & 0.65893 & 0.00114 & 0.00121 & 0.00004 & 19.2 & 5.23 & 0.10 & 116.45 & 2.18 \\
\hline step 7 & 0.304 & 0.00030 & 0.0553 & 0.00015 & 0.00099 & 0.00004 & 0.33131 & 0.00115 & 0.00025 & 0.00002 & 24.8 & 4.13 & 0.12 & 92.67 & 2.58 \\
\hline step 8 & 0.229 & 0.00050 & 0.0415 & 0.00011 & 0.00085 & 0.00004 & 0.24364 & 0.00115 & 0.00011 & 0.00002 & 29.0 & 4.74 & 0.15 & 105.94 & 3.40 \\
\hline step 9 & 0.815 & 0.00105 & 0.1200 & 0.00020 & 0.00239 & 0.00003 & 0.72330 & 0.00233 & 0.00071 & 0.00002 & 41.0 & 5.04 & 0.06 & 112.27 & 1.33 \\
\hline step 10 & 0.532 & 0.00047 & 0.0883 & 0.00016 & 0.00184 & 0.00004 & 0.53427 & 0.00233 & 0.00043 & 0.00002 & 49.9 & 4.58 & 0.08 & 102.41 & 1.71 \\
\hline step 11 & 0.482 & 0.00059 & 0.0972 & 0.00022 & 0.00181 & 0.00003 & 0.55508 & 0.00233 & 0.00028 & 0.00003 & 59.7 & 4.12 & 0.09 & 92.28 & 1.94 \\
\hline step 12 & 0.608 & 0.00053 & 0.1233 & 0.00029 & 0.00222 & 0.00005 & 0.71663 & 0.00233 & 0.00035 & 0.00002 & 72.1 & 4.09 & 0.05 & 91.61 & 1.27 \\
\hline step 13 & 0.806 & 0.00078 & 0.1517 & 0.00034 & 0.00285 & 0.00004 & 0.85636 & 0.00233 & 0.00056 & 0.00003 & 87.4 & 4.23 & 0.06 & 94.74 & 1.31 \\
\hline step 14 & 0.385 & 0.00056 & 0.0912 & 0.00024 & 0.00175 & 0.00004 & 0.53028 & 0.00234 & 0.00014 & 0.00002 & 96.5 & 3.76 & 0.07 & 84.48 & 1.66 \\
\hline step 15 & 0.132 & 0.00020 & 0.0343 & 0.00013 & 0.00057 & 0.00003 & 0.20564 & 0.00234 & 0.00007 & 0.00002 & 100.0 & 3.26 & 0.19 & 73.41 & 4.27 \\
\hline $\begin{array}{l}\text { Av. Blank } \\
1-8\end{array}$ & 0.0025 & 0.00005 & 0.00008 & 0.00001 & 0.00003 & 0.00001 & 0.00070 & 0.00002 & 0.00003 & 0.00001 & & & & & \\
\hline $\begin{array}{c}\text { Av Blank } \\
9-15\end{array}$ & 0.0012 & 0.00004 & 0.00004 & 0.00001 & 0.00003 & 0.00001 & 0.00057 & 0.00001 & 0.00004 & 0.00001 & & & & & \\
\hline
\end{tabular}

Table 2; tabled data are blank corrected. Background measurements bracket every 1-2 samples. The correction factors used were: $\left({ }^{39} \mathrm{Ar} /\right.$ $\left.{ }^{37} \mathrm{Ar}\right) \mathrm{Ca}=0.00065, \quad\left({ }^{36} \mathrm{Ar} /{ }^{37} \mathrm{Ar}\right) \mathrm{Ca}=0.000265, \quad\left({ }^{40} \mathrm{Ar} /{ }^{39} \mathrm{Ar}\right) \mathrm{K}=0.0085$ based on analyses of $\mathrm{Ca}$ and $\mathrm{K}$ salts. Analyses were also corrected for mass spectrometer discrimination. The branching ratio of Steiger and Jaeger (1977) were used.

\section{4. $K-$ Ar analysis}

A whole-rock $\mathrm{K}-\mathrm{Ar}$ age determination of a phyllonite (sample FC0851) was carried out at the Center for Geochronological Research at the University of São Paulo. Laboratory procedures for potassium and argon analyses followed those previously described by Amaral et al. (1966). In this manner, argon is extracted by means of total fusion of the samples in a molybdenum-crucible by induction heating in an ultra-high vacuum system. A pure ${ }^{38} \mathrm{Ar}$ spike, taken from a pipette-driven reservoir, is used for the isotope dilution measurement, carried out in a Reynolds-type pyrex glass mass spectrometer. Potassium analysis is done by flame photometry, and all samples are run in duplicate, with a degree of reproducibility usually within $1.0 \%$. The precision of the argon analyses depends on the quality of the mass spectrometer isotopic measurements, the ${ }^{38} \mathrm{Ar}$ spike 
calibration against standard sample, and also on the atmospheric argon content of individual extraction. For normal determinations, the total analytical error, calculated considering error propagation, is around $3 \%$ at the $2 \sigma$ level (Table 3 ). Age calculations used the potassium decay constants of Steiger and Jaeger (1977).

\subsection{SHRIMP U-Pb analyses}

Zircon U-Pb crystallization ages of samples of three intrusive rocks (samples FC0853-ST0337-FO0463) that post-date the main tectonic emplacement event of the SOC were carried out. Zircon separates were prepared at the Departamento de Geología, Universidad de Chile, Santiago. U-Pb ages were obtained using the SHRIMP facilities at the Research School of Earth Sciences, Australian National University, in Canberra. Analytical techniques followed those described by Williams (1998). The data were processed using the SQUID Excel Macro of Ludwig (2000) (Table 4). Uncertainties are reported at the $1 \sigma$ level. Corrections for common $\mathrm{Pb}$ were made using the measured ${ }^{238} \mathrm{U} /{ }^{206} \mathrm{~Pb}$ and ${ }^{207} \mathrm{~Pb} /{ }^{206} \mathrm{~Pb}$ ratios following Tera and Wasserburg (1972) as outlined in Williams (1998). The geological time-scale follows that of the IUGS-ICS (http://www.stratigraphy.org/cheu.pdf).

\section{The Canal de las Montañas shear zone and other shear bands}

The SOC, located ca. $100 \mathrm{~km}$ to the west of the present-day front of the Magallanes fold-and-thrust belt (Fosdick et al., 2011; Harambour 2002), is one of the largest belt of Late Jurassic ophiolitic complexes exposed along the continental margin of southern South America. The SOC is juxtaposed over the foliated successions of Upper Jurassic to Lower Cretaceous volcaniclastic and sedimentary rocks (Tobífera Formation and Zapata Formation), which are well-exposed along both shores of the Canal de las Montañas and across Cordillera Riesco (Figs. 1 and 2). The N-S trending band of foliated rocks, which also includes restricted bodies of sheared ophiolitic rocks along its western boundary, is deflected to the west at the northern end of the channel. Northward, the band remains N-S trending and crops out at the eastern end of Seno Encuentros and Seno Lolos, in contact with the diabase/dike ophiolitic level. The SOC is delimited to the west by discontinuous N-S to NNW-SSE trending belts of foliated mafic rocks. Isolated bodies of plutonic complexes and hypabyssal rocks occur within this part of the Patagonian fold-thrust belt. Exceptional undeformed meter-wide dikes of lamprophyric rocks crosscut ophiolitic units, folded shales and siltstones of the Zapara Formation (at Peninsula Garfio), and felsic mylonites of the Tobífera Formation (at Cordillera Riesco) (Anguita, 2010).

In previous structural studies, Forsythe and Allen (1980) documented Paleozoic metasedimentary basement rocks that were polydeformed prior to the Late Jurassic opening of the Rocas Verdes basin. Although pre-Late Jurassic structures were probably reactivated during Andean orogenesis (Allen 1982), this paper focuses on the main structures in the Upper Jurassic-Lower Cretaceous successions that formed during basin closure and tectonic emplacement of

Table 3

Experimental data for whole rock K-Ar analyses on phyllonite FC0851.

\begin{tabular}{|c|c|c|c|c|c|}
\hline $\mathrm{K}(\%)$ & $\pm(\%)$ & ${ }^{40} \mathrm{Ar} \operatorname{Rad} \operatorname{ccSTP} / \mathrm{g}\left({ }^{*} 10^{-6}\right)$ & ${ }^{40} \operatorname{Ar} \operatorname{Atm}(\%)$ & Age (Ma) & \pm \\
\hline 2.7342 & 0.50 & 8.74 & 9.44 & 80.4 & 1.8 \\
\hline \multicolumn{6}{|l|}{ Notes: } \\
\hline \multicolumn{6}{|c|}{$\begin{array}{l}\text { 1. The } \mathrm{K} \text { concentration (\%) was obtained by flame photometry and corrected for the } \\
\text { value of the analytical blank. }\end{array}$} \\
\hline \multicolumn{6}{|c|}{ 2. Blank during analysis $<$ method detection limit $(<0.0001 \mathrm{ppm})$. } \\
\hline \multicolumn{6}{|c|}{$\begin{array}{l}\text { 3. The error is calculated as the percentage difference of the duplicate values, according } \\
\text { to the equation: }=\% \text { Diff. * } 75 / 100 \text {. }\end{array}$} \\
\hline \multicolumn{6}{|c|}{$\begin{array}{l}\text { 4. The average concentration (\%) of BRP- } 1 \text { standard for the analysis was } 1.3 \% \text {. } \\
\text { 5. Value of total spike is } 49.14^{*} 10^{-11} \mathrm{Ar}^{38} \text { moles. }\end{array}$} \\
\hline
\end{tabular}

ophiolitic complexes. Thus, the foliation notation used here considers that $S_{0}$ represents the original bedding or stratification of Upper Jurassic-Lower Cretaceous volcanic and sedimentary rocks of the Rocas Verdes basin. Phengitic composition of white mica from selected samples is presented in Table $1 \mathrm{a}$.

\subsection{Meso-and micro-scale mineralogy and structural fabrics}

The Canal de las Montañas Shear Zone (CMSZ) constitutes of predominantly metamorphosed tectonic thrust slices consisting of Upper Jurassic-Lower Cretaceous foliated silicic crystal tuffs and siltstones, with restricted occurrences of metabasalts and metacherts. Original bedding or volcanic flow stratification structures, which are preserved along the eastern domain of the CMSZ, are progressively obliterated by dynamic recrystallization to the west, as described below.

The internally faulted and folded tectonic slices of the Tobífera and Zapata formations exposed along Cordillera Riesco (Fig. 4a), consist of meter-thick piles of variably recrystallized crystal lapilli tuffs (Fig. 5ab), welded tuff and local quartz-bearing siltstones (Galaz et al., 2005). At Cerro Ratón (Fig. 2), the N-S striking volcanic and sedimentary succession dip $40-50^{\circ}$ to the west $\left(\mathrm{S}_{0}\right)$ and exhibits a heterogeneous anastomosing and roughly $\mathrm{N}-\mathrm{S}$-trending cleavage with $\mathrm{S}$-C-type shear bands $\left(S_{1}, D_{1}\right.$; Fig. $\left.4 \mathrm{~b}\right)$ that steeply $\left(>70^{\circ}\right)$ dip to the west, sub-parallel to the axial plane of meter-sized asymmetric and tight folds $\left(F_{1}\right)$. Boudinage and zones of disrupted competent rocks occur in sparse meter-thick strata with heterogeneous components, which are probably derived from precursor peperite deposits. Lithic fragments of fine-grained and layered sedimentary rocks occur in sheared tuffs. Interleaved meter-thick beds of quartz-bearing siltstone show a slaty cleavage, strongly dipping to the west and sub-parallel to the foliation of metatuffs. Brittle structures include centimeter-sized tension gashes, mostly filled with quartz, and sparse sub-vertical and roughly E-W to NE-SW trending kink bands.

Mylonites that formed from felsic volcaniclastic rocks consist of variable proportions of quartz and feldspar porphyroclasts in a finegrained, felsitic recrystallized matrix. Aligned fluid inclusions in deformed quartz porphyroclasts are characteristic of this mylonite. Metamorphic phases consist of variable proportions of phengite, chlorite, epidote, titanite, rare stilpnomelane and fine grained quartzo-feldspathic aggregates (Galaz et al., 2005). Phengite commonly occurs around porphyroclasts in mylonitic microstructures such as symmetric and asymmetric quarter mats, and occurs with chlorite, quartz and oxidized stiplnomelane in strain shadows and in interboudin domains between stretched porphyroclasts. Phyllosilicates show local deflection around rotated porphyroclasts. Metamorphosed quartzose siltstones are partially recrystallized to very fine-grained quartz, white mica, stilpnomelane and titanite.

At Caleta Fondeo (Fig. 2), roughly N-S trending dolerite sills within the Tobífera Formation, with geochemical affinities with ophiolitic rocks (Anguita, 2010), are strongly recrystallized to chlorite, titanite, rare epidote, and quartz, and show restricted shear cleavage along their margins associated with the main episode of deformation $\left(D_{1}\right)$. Further to the west, along the eastern coast of the Canal de las Montañas, foliated Tobífera rocks show similar structures and mineralogy. Folded hemipelagic sedimentary rocks of the Zapata Formation show a penetrative $\mathrm{N}-\mathrm{S}$-trending slaty cleavage, sub-parallel to axial surface of centimeter- to meter-sized isoclinal and tight asymmetric folds $\left(S_{1}, F_{1}, D_{1}\right.$; Fig. 2). This tightly folded package of siltstone and sandstone successions show penetrative axial plane cleavage deflected around detrital crystals and radiolaria. Sub-parallel sheath folds in these rocks are present, in addition to disrupted quartz microveins and quartz slickenfibres sub-parallel to the main foliation.

The rocks which crop out along the western coast of the Canal de las Montañas, as well as foliated felsic metatuffs, greenschists and metacherts, have a general $\mathrm{N}-\mathrm{S}$ trending and millimeter- to centimeter- 


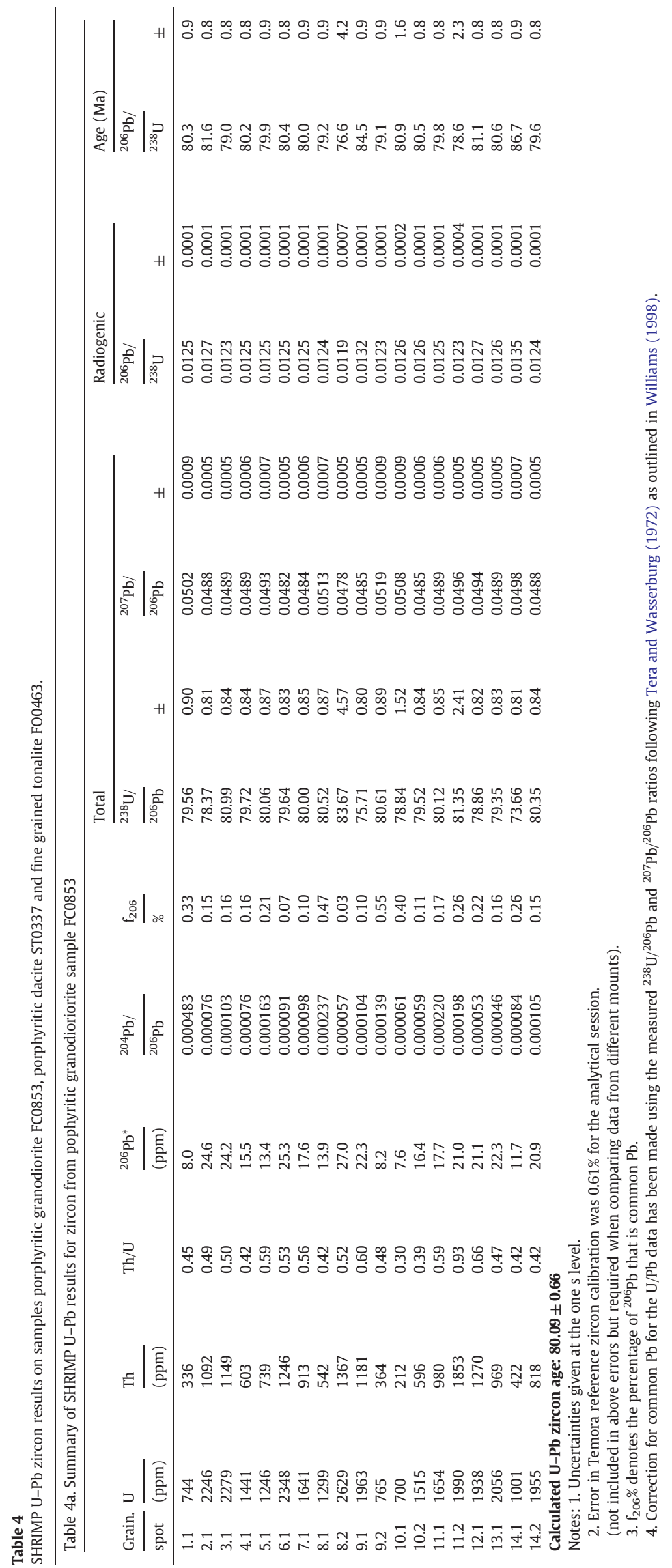

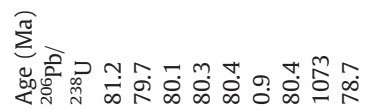

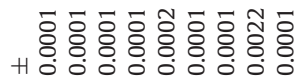

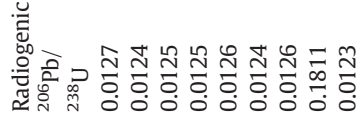

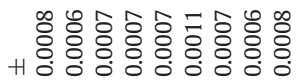

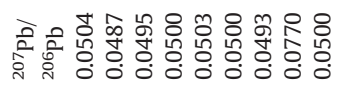

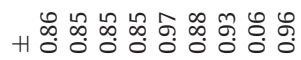

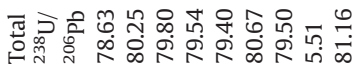

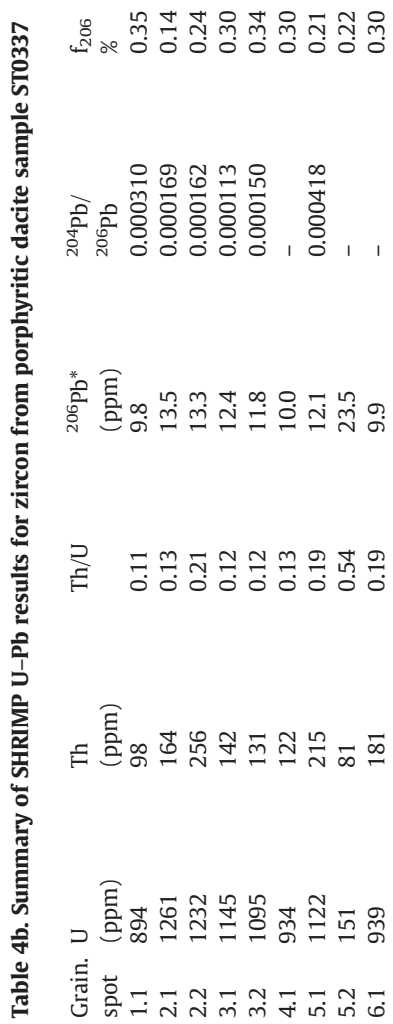




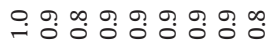

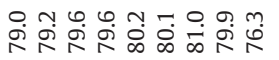

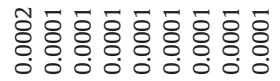

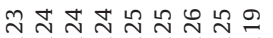

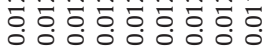

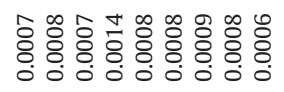

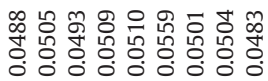

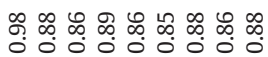

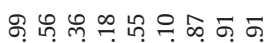
○ं किष

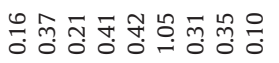

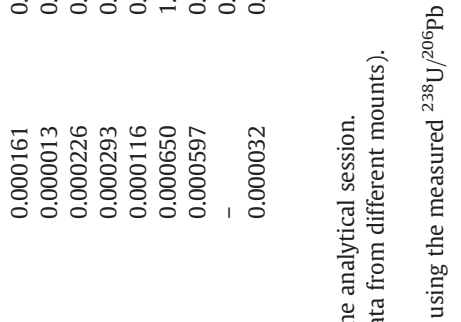

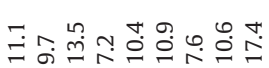

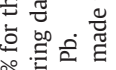

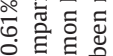

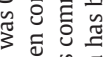

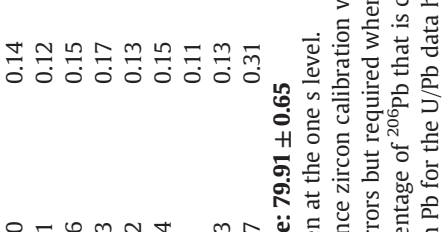

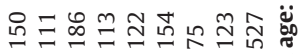

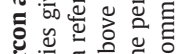

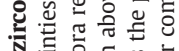

空

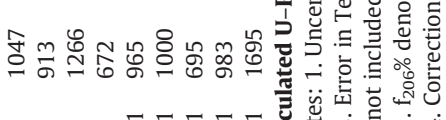

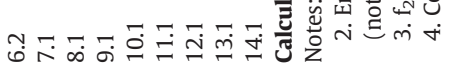

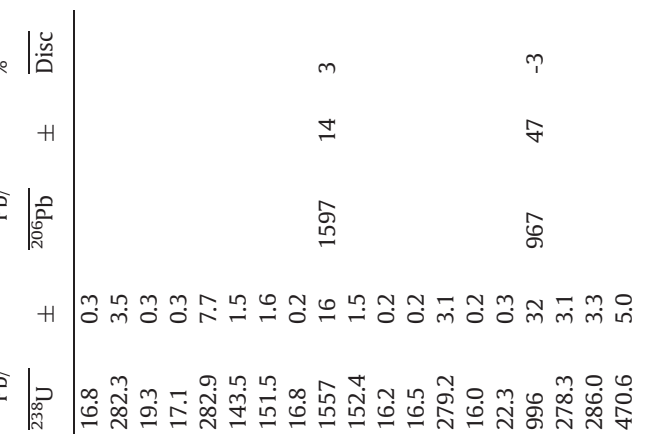

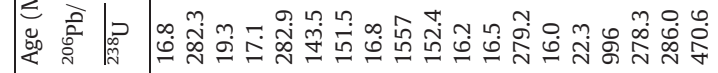

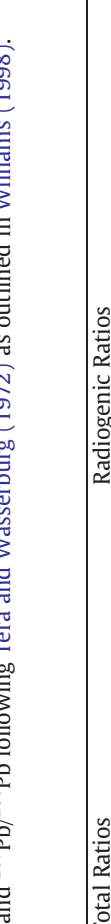

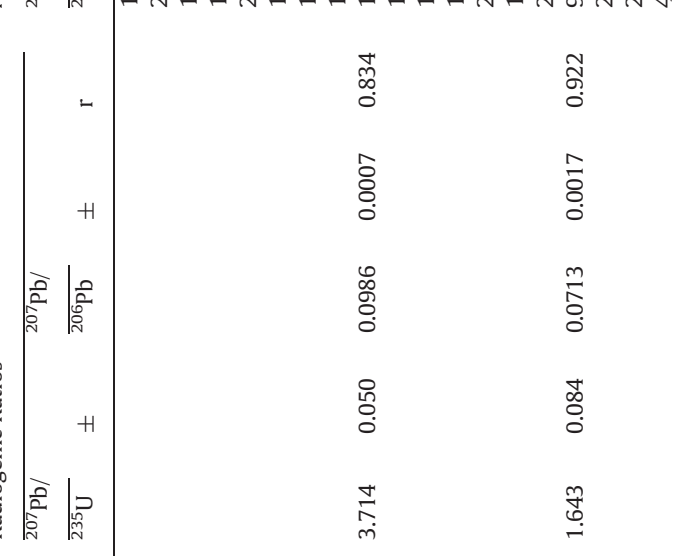

五

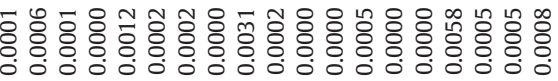

差|

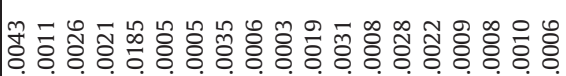

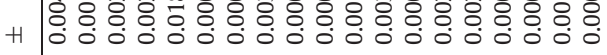

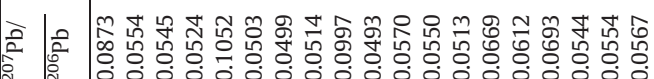
0000000000000000000

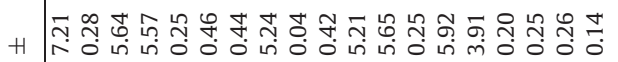

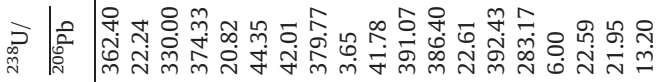
总 |

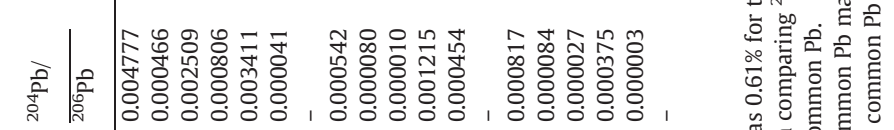
* 高 ₹

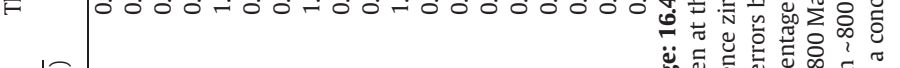

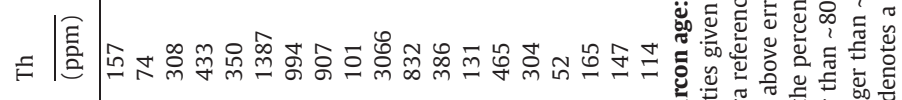

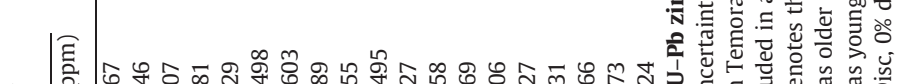

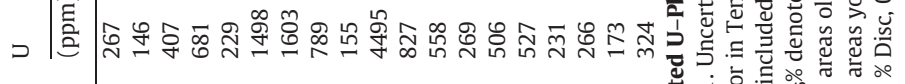

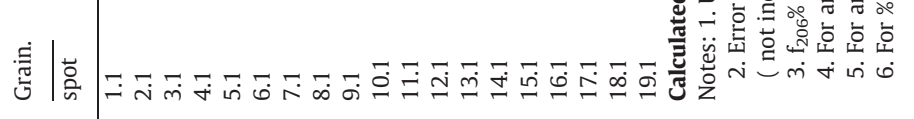



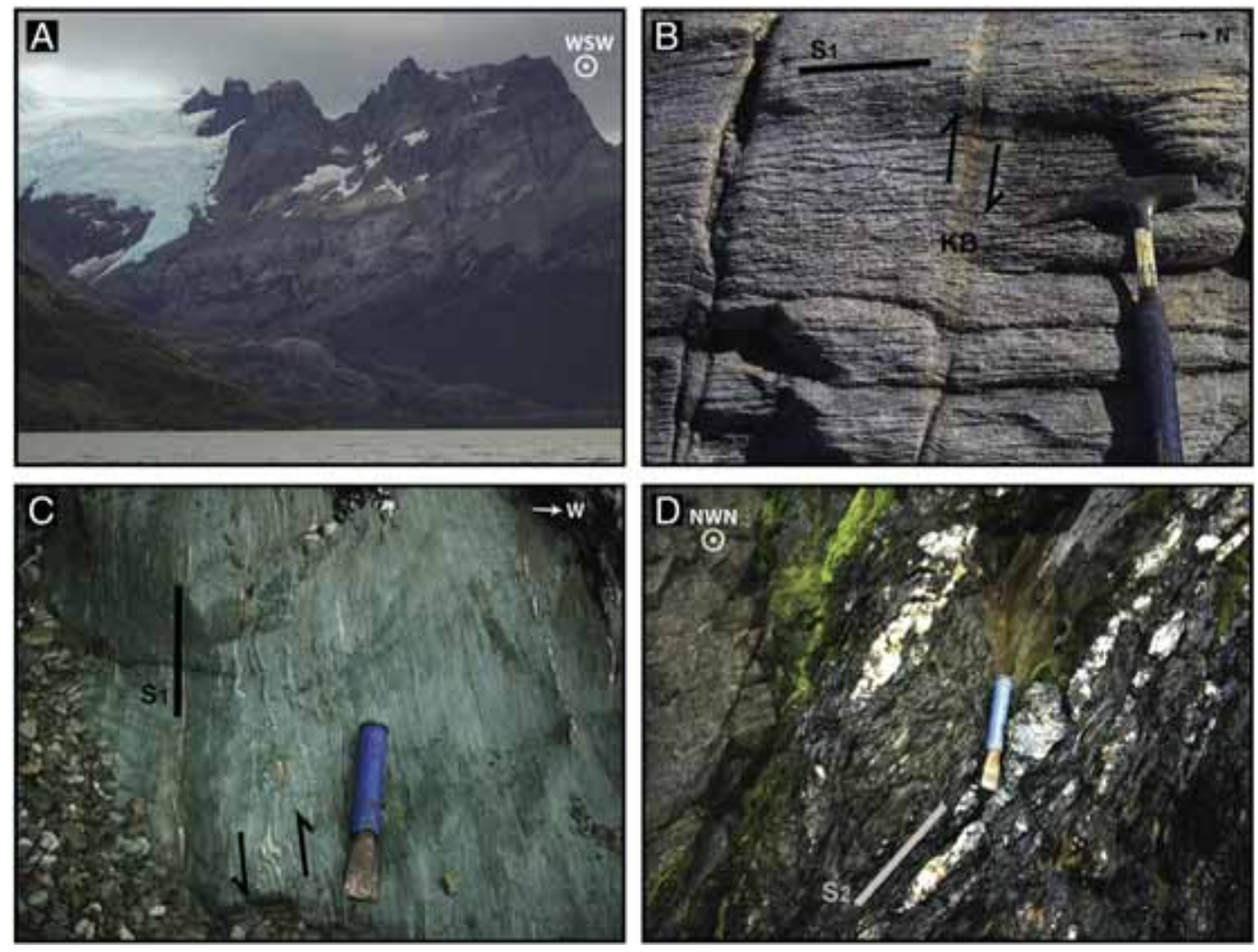

Fig. 4. Photographs of: (a) stratification of the Tobífera Formation along the western flank of Cordillera Riesco viewed from Seno Lolos; (b) anastomosed $S_{1}$ mylonitic foliation of metatuffs with late kink cleavage at Cerro Ratón (Cordillera Riesco); (c) felsic phyllonites with sinistral shear sense indicators associated to late crenulation cleavage at the end of Seno Encuentros; (d) west-vergent foliation $\left(\mathrm{S}_{2}\right)$ of greenschists with tightly folded quartz veins at the entrance of Seno Encuentros.

spaced anastomosed primary composite $\mathrm{S}-\mathrm{C}^{\prime}$-type foliation $\left(\mathrm{S}_{1}\right)$. This structural belt generally dips steeply to the west or is subvertical and regularly exhibits steep stretching lineations $\left(\mathrm{L}_{1}\right.$; Fig. 2). Foliated felsic metatuffs bear metamorphic phases such as phengite, chlorite, stilpnomelane and a very fine-grained quartzo-feldspathic recrystallized matrix (Fig. 5c-d). Plagioclase porphyroclasts show microfaulting and microboudinage structures, the latter with oriented ribbons of quartz and/or stilpnomelane and chlorite in interboudin domains. Boudinaged quartz and feldspar porphyroclasts display predominantly asymmetric strain shadows of quartz and phyllosilicates that define a stretching lineation (Fig. 5d-e). The fine-grained matrix shows a strongly preferred orientation defined by microcrystalline quartz and feldspars. Foliated metabasic rocks show strongly orientated actinolite and chlorite porphyroblasts wrapped around plagioclase porphyroclasts. Anhedral epidote porphyroclasts with strain shadows of chlorite occur as well. The interleaved foliated metacherts show microscopic compositional layering with strain shadows around quartz pseudomorphs derived from recrystallization of radiolaria.

In the surrounding areas of Seno Lolos and Seno Encuentros (Fig. 3) two outcrop belts of schists and mylonites, with doubly vergent structures, enclose the diabase/dike level of the SOC (Allen, 1982; Calderón et al., 2009). The eastern band, which represents part of the CMSZ, consists from east to west of a km-wide belt of foliated/sheared silicic volcaniclastic rocks of the Jurassic Tobifera Formation with NS- and NNE-trending millimeter- to centimeterspaced west-dipping anastomosing $\mathrm{S}-\mathrm{C}$-type shear cleavage $\left(\mathrm{S}_{1}\right)$. This unit is interbedded with meter-thick lenses of siltstone with penetrative slaty cleavage, delimited to the west by a decameter-belt consisting of openly folded package of siltstone and sandstone beds with tenuous axial plane cleavage. The mineralogy and texture of metatuffs at these localities are comparable to those described in Cordillera Riesco, with variably recrystallized porphyroclasts of feldspars and quartz in a fine grained quartz-rich matrix and oriented aggregates of white mica, chlorite, stilpnomelane and rare biotite. To the west of folded Lower Cretaceous sedimentary rocks (Fig. 3), metabasalts with stretched pillow structures are preserved in meter-sized boudins with sub-centimeter quartz-epidote veins.

In direct contact with Late Jurassic undeformed bimodal intrusive components of the SOC (Allen, 1982; Calderón et al., 2007b) a decameter-wide band comprising interleaved schists and mylonites (previously interpreted as strongly deformed undifferentiated rocks by Allen 1982). Relics of igneous textures and mineral assemblages allow us to interpret that these mylonites have formed during the deformation of mainly precursor silicic volcanic and volcaniclastic rocks and basalts with spatially restricted cherts. Phengite-bearing phyllonites (Figs. 4c-5f) show a continuous east-vergent or subvertical foliation with subvertical stretching lineations, with a discrete crenulation cleavage and associated gently plunging intersection lineation (Fig. 3b).

The SOC is delimited to the west by a roughly NS- to NNW-trending band of chlorite-epidote bearing greenschists with penetrative westvergent foliation, and no discernible stretching lineation (Fig. 4d). Open folded sedimentary rocks of the Zapata Formation with a tenuous subvertical NS-trending axial plane cleavage crops out at Peninsula Garfio and Peninsula Taraba (Fig. 3).

\subsection{The Taraba Thrust}

At Seno Profundo (Fig. 3), variably deformed pillow basalts with minor horizons of radiolarian cherts and shales, and interleaved with sheared silicic volcaniclastic rocks, have shear bands of a dominantly NNW trending and steeply $\left(80-90^{\circ}\right)$ west-dipping anastomosing S-C-type foliation. Quartz tension gashes are widespread, which, like those in Cordillera Riesco, probably formed during 
deformation producing thrusts and folds. The volcaniclastic rocks are composed mainly of plagioclase, K-feldspar and quartz porphyroclasts in dynamically recrystallized matrix in which the foliation is defined by narrow aggregates of chlorite. Deformation lamellae and undulose extinction are present in quartz, and strain shadows and domino microstructures are present in feldspars. Accessory phases include titanite, epidote and opaque minerals. Metabasic rocks preserve relics of clinopyroxene with variable proportions of actinolite, chlorite, titanite, epidote and albite. Porphyroclastic pyrite show strain fringes of quartz and actinolite. This terrane, referred as the bimodal extrusive layer of the SOC (Calderón et al., 2007b), is thrust over the folded and crenulated Zapata Formation to the east (Allen, 1982; Calderón et al., 2007a; Stewart et al., 1971). Sedimentary units in the footwall show penetrative cleavage parallel to the axial plane of a major anticlinal fold. At Peninsula Taraba, the bimodal extrusive layer is probably in fault contact and bounded to the west by terrains of Paleozoic metamorphic rocks and Jurassic granites (Fig. 1).

\section{Deformation mechanisms and kinematics}

Dynamically recrystallized rocks belonging to the CMSZ and other shear bands are not homogeneously developed throughout the whole units. They consist of strongly foliated rocks with different precursor lithologies. Shear bands representative of the CMSZ can be grouped into two categories: (1) quasi-schists or S-C-type proto-mylonites, which prevail along the Cordillera Riesco and represent the eastern band of the CMSZ; and (2) S-C'type mylonites and local phyllonites that are restricted to a sub-kilometer-wide and sub-vertical western band of the CMSZ, onto which the main thrust sheet of the SOC is juxtaposed.

Primary deformation mechanisms, associated with the development of anastomosing mica-rich folia, strain shadows and quarter mats around prophyroclasts of quartz and feldspars, were pressure solution and solution transfer (e.g. Rutter, 1983). These processes involve intergranular fluids that allowed the element redistribution
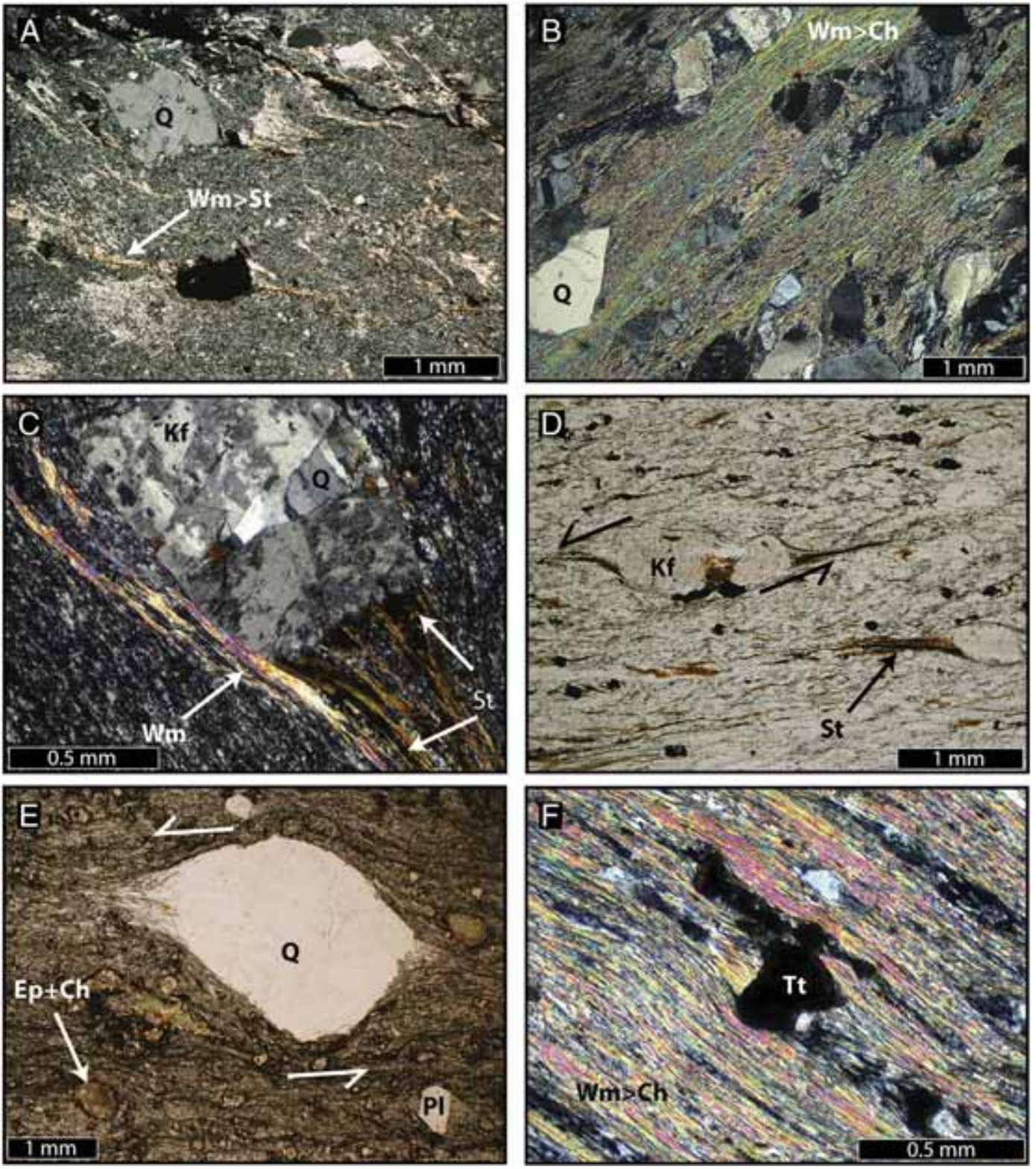

Fig. 5. Photomicrographs (crossed and parallel nicols) showing representative textures and microstructures in thin section. (A) Relatively low-strained felsic metatuff. (B) Relatively high-strained S-C type mylonite with quartz and feldspar porphyroclasts in a highly recrystallized fine grained matrix of mainly phengite (sample ST0402). (C), (D) Highly strained S-C' type mylonite with strain shadows, quarter mats around stretched and boudinaged porphyroclast of feldspars; with preserved kinematic indicators of shear sense (sample ST0302). (D) Highly strained mylonite from recrystallized metatuff with preserved kinematic indicators of shear sense. (E) Highly strained phengite-bearing phyllonite with porphyroclast of titanite and quartz (sample FC0851). Mineral abbreviations are: Ch: chlorite; Wm: white mica; St:stilpnomelane; Q: quartz; Pl:plagioclase; Kf: k-feldspar. 
and crystallization of phyllosilicates (white mica, chlorite, stilpnomelane, rare biotite), quartz and feldspars in low strain domains around porphyroclasts or in shear cleavage. The constant small grain size and equidimensional grain shape of the rock matrix in silicic metatuffs suggest that grain boundary sliding operated during the dynamic recrystallization (e.g. White and White, 1981). Microfaults transecting feldspar porphyroclasts and ubiquitous deformation lamellae in quartz porphyroclasts indicate that rocks underwent processes of intracrystalline deformation and twinning (e.g. Pryer, 1983). Such deformation mechanisms are characteristic of low-grade temperature conditions of metamorphism in the presence of fluid phases, with greater amounts of fluid involved in the development of phyllonites.

The S-C'type mylonites and phyllonites along the western band of the CMSZ are characterized by a well-developed stretching lineation $\left(\mathrm{L}_{1}\right)$, defined by oriented micas and strain shadows around stretched quartz and feldspar porphyroclasts, and thus suitable for a kinematic analysis. Shear sense indicators, viewed at surfaces parallel to the lineation and perpendicular to foliation, such as the shear band cleavage, mantled porphyroclasts ( $\delta$ - and $\sigma$ - type microstructures), quarter mats, strain shadows, strain caps, microfaults or microshear zones in porphyroclastic grains, and microboudinage indicate a bulk reverse sense of shearing (cf. Fig. 5d-e). On the basis of the steeply south-plunging lineations, a dextral component during reverse shear is indicated (Figs. 2-3). One can discern a complex kinematic regime from crenulated phyllonites at Seno Encuentros, where mesoscopic shear sense indicators in stretched quartz veins and boudins suggest a late sinistral sense of shearing (Fig. 4c) with an associated gently plunging intersection lineation.

\section{Phase relations and P-T metamorphic constraints}

The mineral assemblages and microstructures in foliated rocks suggest low-grade metamorphic conditions during the main shearing event. For better geothermobarometric constraints a P-T pseudosection was calculated for a phengite-chlorite-rich phyllonite (sample FC0851; Table 1) collected at Seno Encuentros (Fig. 1-4c). This sample was selected because it exhibits a more pervasive recrystallization compared to other mylonites and schists which commonly have variable amounts of quartz and feldspar porphyroclasts. It is therefore considered that (1) the whole rock composition is representative of the effective bulk composition during the main episode of dynamic metamorphism and (2) metamorphic equilibrium conditions were reached. In addition, for a better interpretation of ${ }^{40} \mathrm{Ar} /{ }^{39} \mathrm{Ar}$ isotopic data on syntectonic phengite a P-T pseudosection was calculated for sample ST0402, in order to constrain the temperature of dynamic metamorphism.

To ascertain predictive phase relations, the minimum Gibbs energy for an average bulk rock composition was calculated for a net of P-T conditions with the computer program package PERPLE_X (Connolly, 1990). Calculations were undertaken in the system $\mathrm{MnO}-\mathrm{Na}_{2} \mathrm{O}-\mathrm{CaO}-$ $\mathrm{K}_{2} \mathrm{O}-\mathrm{FeO}-\mathrm{MgO}-\mathrm{Al}_{2} \mathrm{O}_{3}-\mathrm{SiO}_{2}-\mathrm{H}_{2} \mathrm{O}-\mathrm{O}_{2}$ for the $\mathrm{P}-\mathrm{T}$ range $1-14 \mathrm{kbar}$ and $150-550^{\circ} \mathrm{C}$. We used the thermodynamic data set of Holland and Powell (1988, updated 2002) for mineral and aqueous fluid. The following solid-solution models (see Massonne, 2010; Powell and Holland, 1999), being compatible with this data set, were selected: $\mathrm{Chl}(\mathrm{HP})$ for chlorite, Pheng(HP) for white mica, $\mathrm{Pa}(\mathrm{M})$ for paragonite, Bio(HP) for biotite, Stlp(MN) for stilpnomelane, Carp(M) for carpholite, $\mathrm{Ctd}(\mathrm{HP})$ for chloritoid, fsp11 for plagioclase, Ep(HP) for epidote, Gt(HP) for garnet, $\operatorname{Acm}(\mathrm{M})$ for sodic pyroxene and $\operatorname{Act}(\mathrm{M})$ for amphibole. The final pseudosection was redrawn by smoothing curves as demonstrated by Connolly (2005).

Sample FC0851(Fig. 5d) is a very fine-grained phyllonite derived from a felsic protolith (ca. $72 \mathrm{wt} \% \mathrm{SiO}_{2}$ ), consisting of bands of phengite and chlorite with strongly preferred orientation within an aggregate of quartz and albite with quartz-rich polycrystalline ribbons wrapped around porphyroclasts of polycrystalline quartz, titanite and epidote. Traces of calcite are found in strain shadows. The bulk rock composition (wt\%) is $\mathrm{SiO}_{2}: 71.82, \mathrm{TiO}_{2}: 0.48, \mathrm{Al}_{2} \mathrm{O}_{3}: 13.44, \mathrm{FeO}_{\text {tot }}$ : 3.50, MgO: 2.79, $\mathrm{MnO}: 0.04, \mathrm{CaO}: 0.75, \mathrm{Na}_{2} \mathrm{O}: 2.34, \mathrm{~K}_{2} \mathrm{O}: 2.58$ and $\mathrm{P}_{2} \mathrm{O}_{5}: 0.05$. An oxygen content of $0.039 \mathrm{wt} \%$ was selected corresponding to $10 \% \mathrm{Fe}^{3+}$ of the total iron (see Massonne et al., 2007) and a water content of $3 \mathrm{wt} . \%$, to guarantee a free hydrous fluid phase for a considerable part of the P-T pseudosection, was assumed in the calculation.

The P-T pseudosection (Fig. 6a) reproduces the P-T stability field of the observed mineral assemblages and display consistent mineral phases in those P-T fields in which chlorite, white mica, epidote, titanite, albite and quartz occur between the stilpnomelane-out and biotite-in metamorphic reactions (Fig. 6b). Despite these considerations, the best intersection between the compositional isopleths of phengite ( $\mathrm{Si}$ content of 3.3-3.4 a.p.f.u.) and chlorite ( $\mathrm{X}_{\mathrm{Mg}}$ between 0.60 and 0.62 ) is at $230-260{ }^{\circ} \mathrm{C}$ and $5-6 \mathrm{kbar}$ (Fig. 6c). At these conditions, the predicted stable mineral assemblage is quartz (ca. $44 \mathrm{vol} . \%$ ), phengite (ca. 21 vol.\%), chlorite (ca.11 vol.\%), albite (ca. 17 vol.\%), stilpnomelane (ca. 2 vol.\%), paragonite (ca. 2.3 vol.\%), titanite ( $<1$ vol.\%), lawsonite (ca. 2 vol.\%), clinopyroxene (1.2 vol.\%). The non detected mineral phases stilpnomelane, clinopyroxene, paragonite and lawsonite amount to more than 7 vol.\% of the predicted assemblage but could, nevertheless, be decomposed by late metamorphic overprint.

In addition, there is partial agreement between the observed metamorphic assemblage and the aforementioned compositional isopleths of phengite and chlorite with the calculated assemblages at 400$470{ }^{\circ} \mathrm{C}$ and $7.5-9 \mathrm{kbar}$. The predicted mineral assemblages include quartz (ca. 44 vol.\%), phengite (ca. 22 vol.\%), chlorite (ca.11 vol.\%), albite (ca. 18-20 vol.\%), epidote (ca.1-2 vol.\%) that depending on each stability field appear with variable proportions of paragonite (ca. 2.4 vol.\%), titanite ( $<1$ vol.\%) clinopyroxene ( $<1$ vol.\%), rutile $(<0.5$ vol.\%) and hematite $(<0.1$ vol.\%).

Noticeably, paragonite, clinopyroxene, rutile, stilpnomelane and lawsonite were neither detected under the optical microscope nor with the probe. One explanation for the absence of these predicted minerals in this rock is that paragonite could actually be hidden in the fine-grained white mica layers and/or together with clinopyroxene could have converted back to albite and other phases depending on the pressure-temperature path during exhumation. In addition titanite and epidote are pretectonic in origin and could represent metastable phases that resisted to the effects of dynamic metamorphism. In consideration that stilpnomelane is a common phase in mylonites of the CMSZ, the temperature conditions below ca. $350{ }^{\circ} \mathrm{C}$ are very likely (Hervé et al., 2007a; Massonne and Szpurka, 1997) and thus the intersection at $230-260{ }^{\circ} \mathrm{C}$ and 5-6 kbar metamorphic conditions, near the limit between pumpellyte-actinolite and upper greenschist facies of metamorphism, is clearly preferred.

Sample ST0402 (Fig. 5b) consists of variable proportions of quartz and feldspar porphyroclasts $(\mathrm{Q}>>\mathrm{Pl}>>\mathrm{Kf})$ in a fine grained recrystallized matrix ( $50 \%)$ of mostly quartz, feldspars (minor K-feldspar) and phyllosilicates. Phengite and chlorite are generally located around prophyroclasts in microstructures such as asymmetric quarter mats, strain shadows, strain caps and in interboudin domains between stretched porphyroclasts. Titanite and epidote are accessory phases with traces of calcite. The bulk rock composition ( $w t \%)$ is $\mathrm{SiO}_{2}$ : 73.40, $\mathrm{TiO}_{2}: 0.12, \mathrm{Al}_{2} \mathrm{O}_{3}: 14.29, \mathrm{FeO}_{\text {tot }}: 1.73, \mathrm{MgO}: 1.56, \mathrm{MnO}: 0.01$, $\mathrm{CaO}: 0.20, \mathrm{Na}_{2} \mathrm{O}: 2.58, \mathrm{~K}_{2} \mathrm{O}: 4.34$ and $\mathrm{P}_{2} \mathrm{O}_{5}$ : 0.003 . An oxygen content and water content of $0.019 \mathrm{wt} \%$ and $3 \mathrm{wt} . \%$, respectively, was assumed as explained above.

The predicted mineral assemblages and compositional isopleths of phengite (Si content of 3.33-3.44 a.p.f.u.) in the P-T pseudosection (Fig. 6d) allow us to constrain the maximum temperature and pressure conditions of metamorphism. As first approximation, and considering both, the lack of biotite in the studied samples of the area (Cerro Ratón) and the lowest Si content of phengite (3.33 
(A)

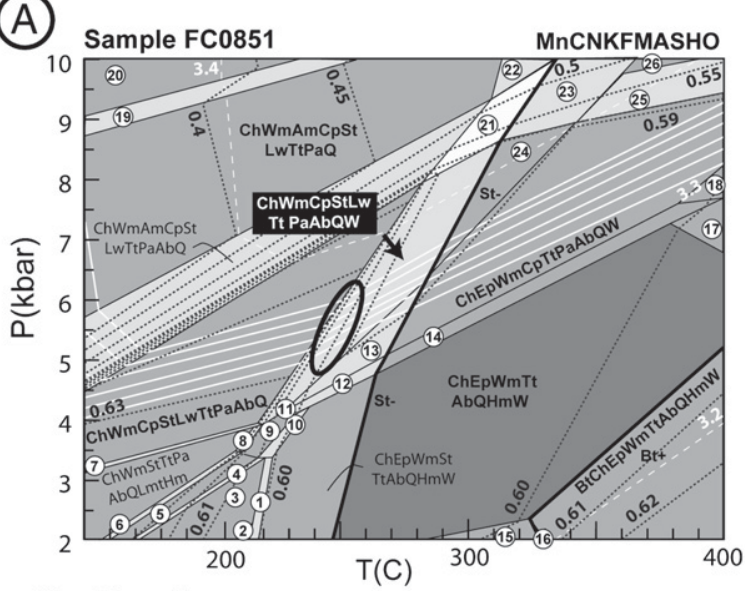

Mineral Assemblages

(1) ChEpWmStTtAbQLmtHmW (2) ChWmStTtAbQLmtHm (3) ChEPWmStTtAbQLmHm (4) ChEpWmStLwTtAbQLmtHm (5) ChWmStLWTtAbQLmtHm (6) ChWmStPaLWTtAbQLmtHm (7) ChWmCpStPaLwAbQHm (8) ChWmStPaLwTtAbQHmW (9) ChWmStLwTtAbQHmW
(B)
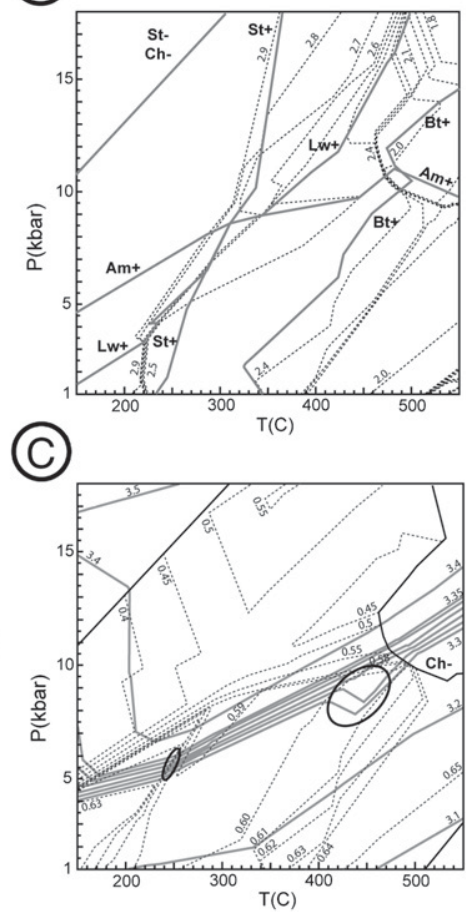

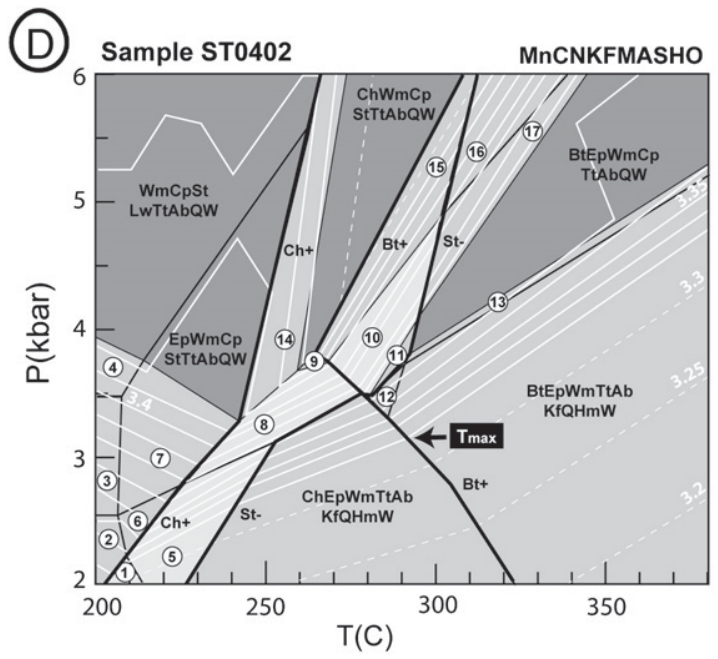

Mineral Assemblages (1) ChWmStTtAbKfQLmtHmW (10) BtChEpWmCpStTtAbQW (2) WmStTtAbKfQLmtHmW (11) BtEpWmCpStTtAbOW (3) WmCPStTtAbKfQLmtW (12) BtEPWmTtAbKfQHmW (4) WmCpStlWTtAbKfQW (5) ChEpWmStTtAbKfOHmW (14) ChEpWmCpStTtAbQW (6) EpWmStTtAbKfQHmW $\quad$ (15) BtChWmCpStTtAbQW (7) EpWmCpStTtAbKf QW (16) BtChWmCpTtAbQW (8) ChEpWmCpStTtAbKfQW (17) BtChEpWmCpTtAbOW (9) ChWmCpStTtAbKfQW

Fig. 6. (a) Pressure-temperature pseudosection calculated for the phengite-chlorite bearing phyllonite (sample FC0851) at Seno Encuentros. (b) Simplified P-T compositional space showing the stability fields of predicted phases and isopleths of volume \% of water content in solids. (c) Solid black lines show the isopleths of Si content in white mica, ranging between 3.3 and 3.35 (see Table X); dashed black lines are the contour lines of the $\mathrm{Mg} /(\mathrm{Fe}+\mathrm{Mg}$ ) ratio in chlorite, ranging between 0.6 and 0.62 . The mineral assemblage present in the rock, Si and $\mathrm{X}_{\mathrm{Mg}}$ isopleths of phengite and chlorite, respectively, restrict the P-T metamorphic conditions to the range of $230-260{ }^{\circ} \mathrm{C}$ and $5-6 \mathrm{kbar}$ (see ellipse). (d) Simplified pressure-temperature pseudosection calculated for the phengite-chlorite bearing S-C-type mylonite (sample ST0402) at Cerro Ratón. In (a) and (b) solid and dashed white lines show the isopleths of $\mathrm{Si}$ content in white mica; dashed lines correspond to the compositional variations measured in the sample. Dashed black lines indicate the $\mathrm{X}_{\mathrm{Mg}}$ isopleths in chlorite. Solid dark lines indicate the disappearance of stilpnomelane and the appearance of chlorite and biotite. The procedures for the P-T pseudosection calculation are indicated in the text. Mineral abbreviations are: Ch: chlorite; Wm: white mica; Lw: lawsonite; Ru:rutile; Mt: magnetite; Hm: hematite; Bt: biotite; Am: amphibole; Cp: clinopyroxene; Gt: garnet; St:stilpnomelane; Q: quartz; W: water; Ab: albite; Pl: plagioclase; Fc: carpholite; Tt: titanite; Lmt: laumontite; Pa:paragonite; Kf: K-feldspar.

a.p.f.u.), the maximum metamorphic temperature have to be ca. $290{ }^{\circ} \mathrm{C}$ at ca. $3 \mathrm{kbar}$. The stable metamorphic mineral assemblage consist of quartz (ca. 38 vol.\%), phengite (ca. 25 vol.\%), chlorite (ca.4 vol.\%), albite (ca. 22 vol.\%), K-feldspar (ca. 7 vol.\%), epidote ( $<1$ vol.\%), titanite ( $<1$ vol.\%), hematite ( $<1$ vol.\%). Otherwise, considering the highest $\mathrm{Si}$ content of phengite (3.44 a.p.f.u.) higher pressure and lower temperature metamorphic conditions are predicted.

\section{Time constraints for dynamic metamorphism}

Two low-grade metamorphic rocks from the CMSZ were dated using ${ }^{40} \mathrm{Ar} /{ }^{39} \mathrm{Ar}$ and $\mathrm{K}-\mathrm{Ar}$ dating techniques. Sample ST0402 contains metamorphic phengite which was dated in situ using an IR laserprobe, and sample FC0851 was dated using whole-rock K-Ar techniques. In addition, two fractions of amphibole separates from lamprophyric dikes (samples ST0411 and FC0853; Fig. 1) were dated by ${ }^{40} \mathrm{Ar} /{ }^{39} \mathrm{Ar}$ step-heating analysis, to constrain the minimum age of the main episode of thrust-folding and shearing in this area. The ${ }^{40} \mathrm{Ar} /{ }^{39} \mathrm{Ar}$ isotopic data are shown in Table 2.

Multiple analysis spots on mats of $10-50 \mu \mathrm{m}$-sized phengite in sample ST0402 yielded a mixed set of apparent ${ }^{40} \mathrm{Ar} /{ }^{39} \mathrm{Ar}$ ages from $83.0 \pm 1.2$ to $185.3 \pm 0.8 \mathrm{Ma}$ (Fig. $7 \mathrm{a}$ ). We interpret these ages to result from analysis of a mixture of phases, and/or excess argon, and/ or inherited argon due to incomplete recrystallization. Isochron 
(A)

Phengite from felsic mylonite
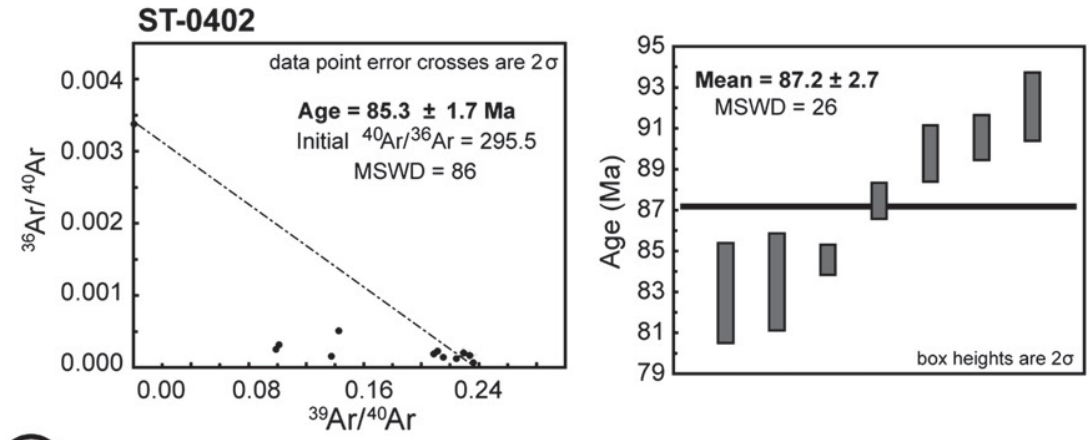

(B)

Amphibole from lamprophyric dikes

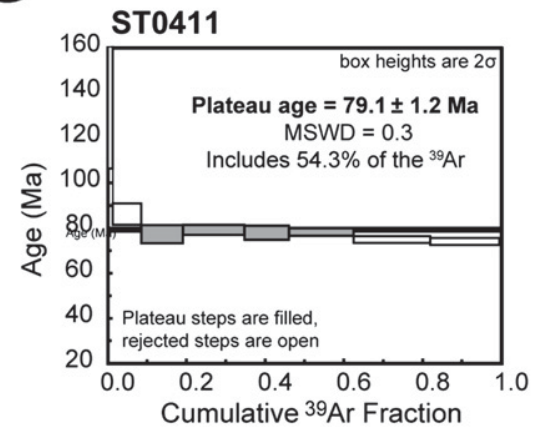

\section{FC0835}

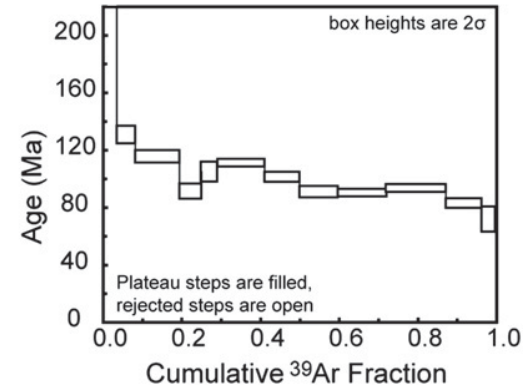

Fig. 7. (A) ${ }^{40} \mathrm{Ar} /{ }^{39} \mathrm{Ar}$ age data for phengite from S-C type mylonite ST0402. (B) ${ }^{39} \mathrm{Ar}$ release spectra for amphibole from lamprophyre samples ST0411 and FC0835.

analysis of all data points shows significant scatter, with the data points spreading out along the radiogenic axis (Fig. 7a). An isochron pinned at the atmospheric air composition through the youngest apparent aged samples yields an apparent isochron age of $85.3 \pm 1.7 \mathrm{Ma}$ (Fig. 7a). We interpret this age as indicating a minor component of contamination from excess argon, inherited argon or a mixture of phases. Despite this, the age points towards a Late Cretaceous metamorphic event.

The whole-rock K-Ar analysis of a phyllonite at Seno Encuentros (FC0851) yields an age of $80.4 \pm 1.8 \mathrm{Ma}$. The ${ }^{40} \mathrm{Ar}$ measurement of this sample, with relatively high amounts of $\mathrm{K}_{2} \mathrm{O}$ ( 2.7\% wt.\%), was of adequate analytical quality (Table 3 ). This age is interpreted as representing the timing of recrystallization or cooling below the $\mathrm{K}-\mathrm{Ar}$ closure temperature for the whole phyllonite.

The lamprophyres are isotropic, fine-grained porphyritic rocks with variable proportions $(<15 \%)$ of chlorite pseudomorphs after olivine, clinopyroxene (diopside, rare augite) and brown amphibole (magnesiohastingsite; Table 1b) and interstitial and/or intergranular groundmass with interstitial chlorite. Step-heating of $0.5-1 \mathrm{~mm}$ diameter amphiboles from sample ST0411 (in close proximity to sample ST0402), yielded a plateau age of $79.1 \pm 1.2$ Ma from 4/9 steps in the experiment (Fig. 7b). The ${ }^{37} \mathrm{Ar} /{ }^{39} \mathrm{Ar}$ ratio suggests some mixing of variable Ca-concentration components. This age is interpreted as representing the timing of amphibole cooling following crystallization during dike emplacement.

The 0.5-1 mm diameter amphiboles in sample FC0835 (Peninsula Garfio), are characterized by narrow rims of actinolite and yielded a staircase-shaped ${ }^{37} \mathrm{Ar} /{ }^{39} \mathrm{Ar}$ step-heating pattern (Fig. 7b). The ${ }^{37} \mathrm{Ar} /$ ${ }^{39} \mathrm{Ar}$ ratio suggests degassing of a mixture of compositions (varying Ca-concentration). The youngest step age, at $73.4 \mathrm{Ma}$, suggests that the youngest degassing component of these amphiboles is of Late Cretaceous age, but no further insight is possible with these data. Step-heating experiments on amphiboles from lamprophyres proved less successful, but still point to a Late Cretaceous minimum age of the thrust-folding and shearing event.

\section{Geochronology of plutonic and hypabyssal rocks}

Plutonic and hypabyssal rocks within the fold-thrust belt were dated using zircon $\mathrm{U}-\mathrm{Pb}$ in-situ methods (Table 4) to constrain an upper age limit on the ophiolite obduction phase of deformation. Geobarometric constraints, using the composition of hornblende, were carried out to constrain the emplacement depths of these plutonic rocks, thereby providing additional information on the magnitude of tectonic uplift and relative exhumation between the SOC and CMSZ domains.

At Seno Encuentros, the deep portion of the SOC is intruded by a NS-trending amphibole-bearing granodioritic pluton that according to Allen (1982) is delimited to the east by an east-vergent thrust fault (Fig. 3). At sea level, and apparently near its eastern limit, fineto medium-grained tonalite/granodiorite with dioritic screens contain xenoliths of pyroxene-amphibole-biotite gneissic rocks with centimeter-thick veins of amphibole tonalite. Higher in the vertical section of this plutonic complex, a porphyritic amphibole-biotite granodiorite crop out and is characterized by the large subhedral crystals of K-feldspar and traces of magmatic titanite. Feldspars exhibit minor replacement by argillites and biotite is partially chloritized. Microveins filled with epidote also occur. Two samples from the same outcrop were analyzed for U-Pb geochronology (FC0853) and mineral chemistry (FC0854). Sixteen analysis yielded a best fit age of $80.09 \pm 0.44 \mathrm{Ma}(\mathrm{MSWD}=0.73)$ (Fig. 8a). Amphibole crystals in the porphyritic granodiorite show complex oscillatory zoning characterized by dark and pale grey domains in back-scattered electron images, of Mg-hornblende and edenite composition, respectively. Edenite is characterized by higher contents of $\mathrm{Al}$ in the tetrahedral site and of alkalis in the A-site (Table 1b). Geobarometry of Al-content in Mg-hornblende (Schmidt, 1992) suggest pressure crystallization conditions as high as 3 kbar.

At Seno Benavente (Fig. 3), in the sheeted dike level (Allen, 1982), a restricted tabular body of amphibole-bearing porphyritic dacite (sample ST0337) crops out. This rock consists of subhedral, up to 

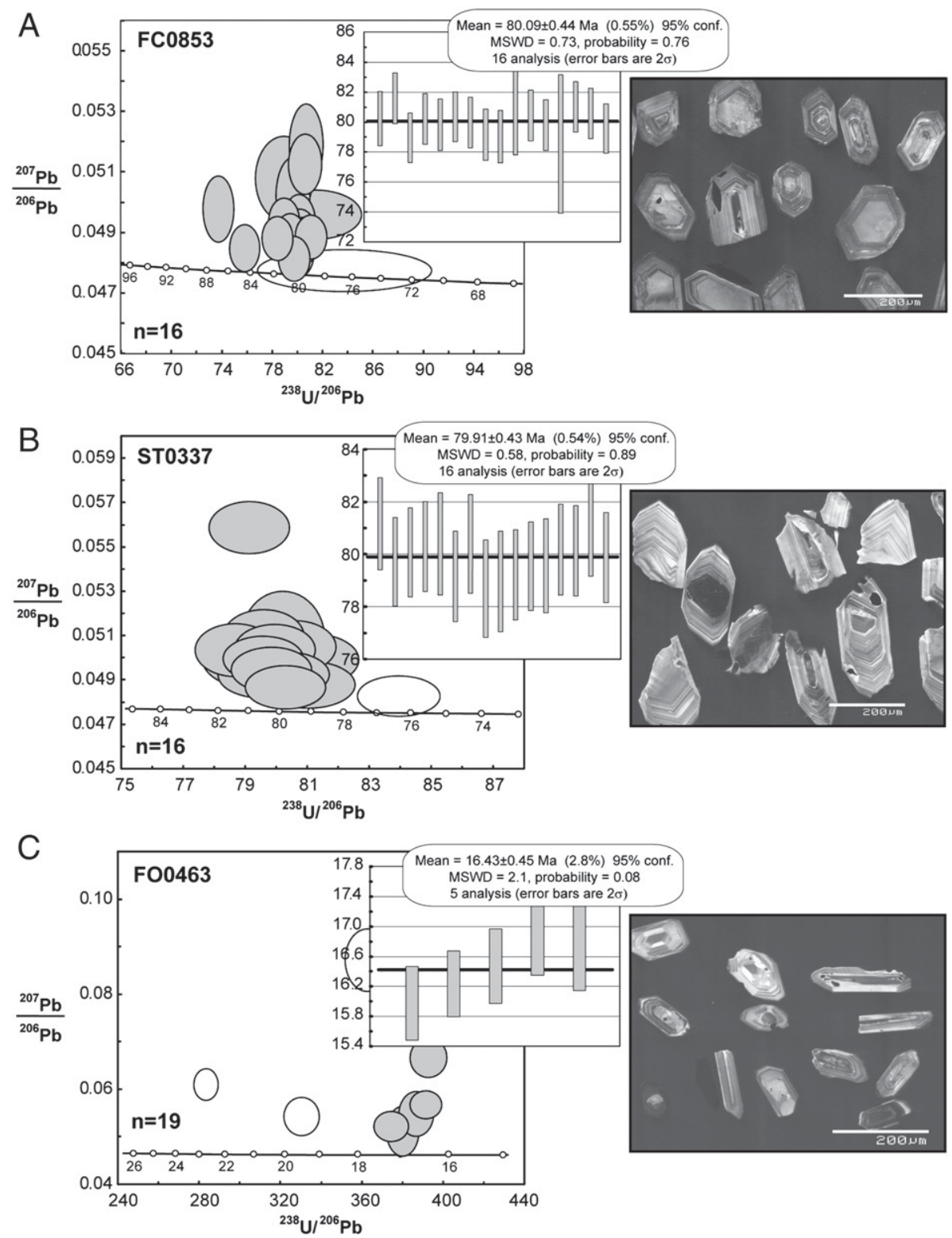

Fig. 8. SHRIMP U-Pb isotopic data from zircon. (A), (B) and (C), show Tera-Wasserberg concordia plots, calculated mean ages (with errors reported at the $2 \sigma$ level) and cathodoluminescence images of analyzed zircons for samples FC0853 (porphyritic amphibole-biotite granodiorite), ST0337 (porphyritic amphibole dacite) and F00463 (biotite tonalite), respectively.

$4 \mathrm{~mm}$ wide phenocrysts of plagioclase (20\%), hornblende (7\%) and quartz (3\%). The aphanitic groundmass is made up of feldspars, quartz and traces of apatite. Amphibole phenocrysts bear inclusions of plagioclase and are variably replaced by an aggregate of chlorite, epidote and carbonate. The analysis of sixteen zircon grains yield an age of $79.91 \pm 0.43 \mathrm{Ma}(\mathrm{MSWD}=0.58)$ (Fig. 8b); an isolated grain of ca. $1073 \mathrm{Ma}$ indicate the involvement of Grenvillian components in the formation of this rock (Table 4).

At Bahía Intricate (Fig. 3), fine grained biotite tonalite, referred to as the Intricate Pluton, intrudes hornfelsic shales, metabasalts and $\mathrm{Pa}-$ leozoic metasedimentary rocks (Allen, 1982). The tonalite (sample FO0463) is composed of anhedral quartz with undulose extinction and subhedral crystals of plagioclase with oscillatory zonation and subordinately replaced by carbonate. Biotite is partially replaced by variable amounts of chlorite and epidote. Studied samples bear inclusions (up to $0.1 \mathrm{~mm}$ in size) of hornfelsic and fine-grained rocks with quartz, plagioclase, and decussate biotite. The analysis of 5 grains generated an average igneous crystallization age of $16.43 \pm 0.45 \mathrm{Ma}$ $(\mathrm{MSWD}=2.1$ ) (Fig. $8 \mathrm{c}$ ). Inherited zircons of Jurassic, Permian and
Mesoproterozic ages are also present, consistent with the presence of microscopic rock inclusions incorporated during magma evolution, ascent and/or final emplacement in the upper crust.

\section{Discussions}

The CMSZ between $51^{\circ}$ and $52^{\circ} \mathrm{S}$ constitutes variably deformed bands of low-grade schists and mylonites derived from felsic ignimbritic, pelitic and mafic rocks, which formed part of the Late Jurassic to Early Cretaceous Rocas Verdes quasi-oceanic basin floor. Shear bands and plutons within the fold-and-thrust belt provide a record of the tectonic evolution and emplacement of ophiolitic thrust stacks during the basin closure and the early arc-continent collision phase of the Andean orogeny. The details regarding how deformation was partitioned, what factors control this process, the timing of deformation and the regional development of an accretionary wedge during the Rocas Verdes basin closure are topics of continued debate. Nonetheless, new structural observations, geochronology and thermobarometry results elucidate important constraints on these events. Here we discuss 
the significance of the CMSZ in accommodating deformation during the tectonic emplacement of the SOC.

\subsection{Fluid-assisted dynamic recrystallization in a subduction setting}

Shear zones represent channels for upward moving fluids (cf. Bebout and Barton, 1989) and fluid infiltration may assist dynamic recrystallization by processes of ionic transfer along chemical potential gradients and reaction softening (Wintsch et al., 1995), which can weaken the rocks (Tullis et al., 1996) and promote strain localization (van Staal et al., 2001). Mineralogical and microstructural data from the CMSZ record the transition from moderately strained felsic volcanic rocks into high-strain mylonites through processes of pressure solution, solution transfer, boudinage, grain size reduction of porphyroclasts and dynamic recrystallization of fine-grained rock matrix operating in the presence of fluids. Situated along the contact with the main ophiolitic stack, the western band of mylonites and phyllonites within the CMSZ, some of which lack porphyroclasts, indicate that strain localization was facilitated by large amount of fluids.

Calculated pressure-temperature conditions on a phyllonite developed during the main event of dynamic metamorphism, at ca. 5-6 kbar and $230-260{ }^{\circ} \mathrm{C}$ (Fig. 6a), is consistent with microstructures, mineral assemblages and previous geothermobarometric results obtained from phengite-stilpnomelane-chlorite foliated metarhyolites within the northern prolongation of the CMSZ (Fig. 9; Hervé et al., 2007a). Pressure-temperature constraints are likely associated with a low geothermal gradient (ca. $10-18{ }^{\circ} \mathrm{C} / \mathrm{km}$ ) indicating that the main shearing event in the CMSZ proceeded under similar pressure-temperature conditions to those documented in subduction settings (cf. Aoki et al., 2008; van Staal et al., 2001). If subduction progressed during a prolonged period of time, a potential source of aqueous fluids could have been heated rocks that dehydrate at low temperatures as given, for instance, by Massonne and Willner (2008). An important candidate for releasing $\mathrm{H}_{2} \mathrm{O}$ is chlorite in meta-felsic rocks, the decomposition of which might occur at ca. 10 kbar and $450-500{ }^{\circ} \mathrm{C}$ (Fig. 6b).

The CMSZ structurally underlies the SOC which preserves greenschist to amphibolite facies metamorphic assemblages and textures associated with ocean floor-type hydrothermal metamorphism (Stern et al., 1976; Elthon and Stern, 1978). Although the SOC was subsequently buried enough to be intruded by the Campanian granitoid suite, we document a significant break in metamorphic pressure

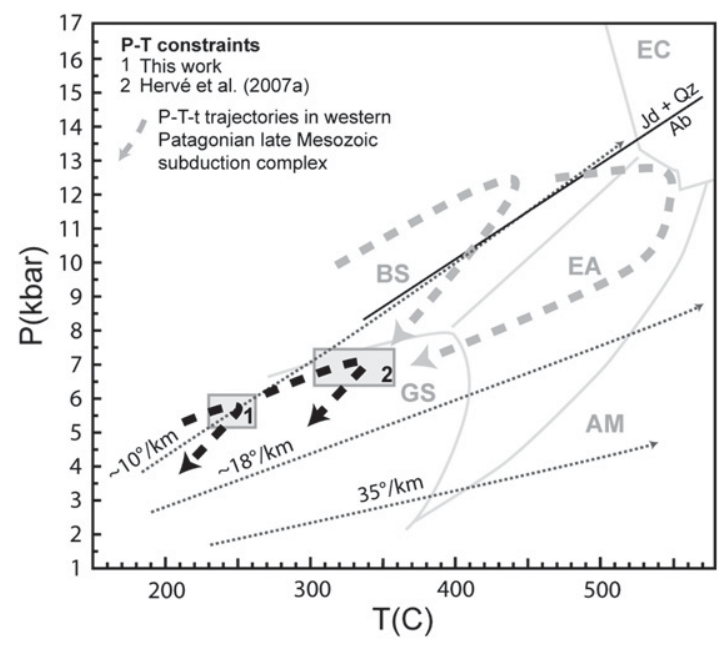

Fig. 9. Pressure versus temperature diagram showing calculated $\mathrm{P}-\mathrm{T}$ conditions for mylonitic rocks of the CMSZ. Boxes indicate assumed error for the P-T conditions estimated in this study and previous data from Hervé et al. (2007a). P-T trajectories for the Late Mesozoic Diego de Almagro Metamorphic Complex are from Willner et al. (2004). Abbreviations of metamorphic facies are: AM, amphibolite; BS, blueschist; EA, epidote amphibolite; EC, epidote eclogite; GS, greenschist. between the ophiolite and the structurally underlying metamorphic rocks. On the basis of the definitions of the tectonic emplacement mechanisms of ophiolites (cf. Wakabayashi and Dilek, 2003), the western band of low-grade phyllonites and mylonites of the CMSZ represents the ophiolitic metamorphic sole, with pressure-temperature conditions transitional between pumpellyte-actinolite and upper greenschist metamorphic facies.

\subsection{The accretionary wedge model and possible westward subduction}

Several different episodes of deformation and their associated structures originated during the tectonic emplacement of the SOC. These features are recognized in the hinterland of the Magallanes fold-and-thrust belt, in which $\mathrm{D}_{1}$ - and $\mathrm{D}_{2}$ - high-angle shear zones define the limits of the main ophiolitic stack of the SOC as a $8-10 \mathrm{~km}$ wide doubly vergent structure (Fig. 10a).

The main deformation event $\mathrm{D}_{1}$, defined by the pervasive mylonitic cleavage in the CMSZ, records a phase of continent-directed thrusting during the Rocas Verdes basin closure. Because the regional $\mathrm{N}-\mathrm{NNW}$ trending and west-dipping to subvertical main foliation $\left(\mathrm{S}_{1}\right)$ is sub-parallel to the axial plane of major open and tight anticlinesyncline folds and reverse faults (Figs. 2-3), the heterogeneous shearing was likely associated with east-vergent thrust-folding deformation (cf. Allen, 1982) and consecutive imbrication of thrust sheets (Fig. 10b-c). The deformation event $\mathrm{D}_{2}$ resulted in west-vergent structures and a shear band foliation located to the west and structurally below the main ophiolitic stack of the SOC. The opposite vergence of $\mathrm{D}_{2}$-related structures is likely associated with the back-folding of an imbricated thrust system. Imprecise is the interpretation of local crenulation cleavage and late sinistral shearing recorded in phyllonites of the CMSZ which can be associated either to a later-stage of progressive shearing during $\mathrm{D}_{1}$ or to the deformation event $\mathrm{D}_{2}$. Similarly, the discrete and sparse subvertical and roughly NE-SW to E-W trending kink bands in mylonitic rocks of the CMSZ can be associated either with a later-stage of imbrications, structural doming and uplift of the metamorphic belt during $D_{2}$ or with the potential deformation event $D_{3}$.

The Taraba thrust fault juxtaposes a Late Jurassic bimodal extrusive thrust sheet, with bands of strongly foliated basalts and silicic volcaniclastic rocks, on top of the openly folded and cleaved sedimentary successions of the Zapata Formation (Fig. 10a; Allen, 1982; Calderón et al., 2007a; Stewart et al., 1971). At a regional scale, the intersection between the foliation of bimodal extrusive rocks and the trace of the Taraba thrust indicates that early mylonitized portions of the Rocas Verdes basin floor were detached from a zone of semi-ductile deformation and subsequently thrust onto the folded sedimentary rocks (Fig. 3). It is postulated that shear band cleavage and subsequent thrusting were related to the main deformational event $\mathrm{D}_{1}$.

South of the study area at Canal Gajardo (52 50 'S), imbricated thrust sheets contain rocks of similar precursor lithological associations to those in the CMSZ (foliated rhyolites, pelites and basalts) are exposed in the hinterland of the Magallanes fold-and-thrust belt. At this locality, Harambour (2002) recognized two penetrative foliations indicating that structural juxtaposition resulted from the progressive growth of an accretionary wedge $\left(D_{1}, S_{1}\right)$. It is postulated by this author that back-folding of the imbricated tectonic slices accompanied the late development of back-thrusts $\left(D_{2}, S_{2}\right)$ and subsequent ophiolite uplift. Comparable lithological associations and structural features in the Canal de las Montañas and Canal Gajardo areas reveal a regional development of an accretionary wedge during the Rocas Verdes basin closure.

Several authors have proposed that the Rocas Verdes basin closure involved the west-dipping subduction and/or underthrusting of the continental platform beneath the drifted magmatic arc (Cunningham, 1995; Gealey, 1980; Hervé et al., 2007a; Klepeis et al., 2010; Kraemer, 2003). This interpretation seems plausible considering the pressuretemperature constraints and that the steepening of early foliation 

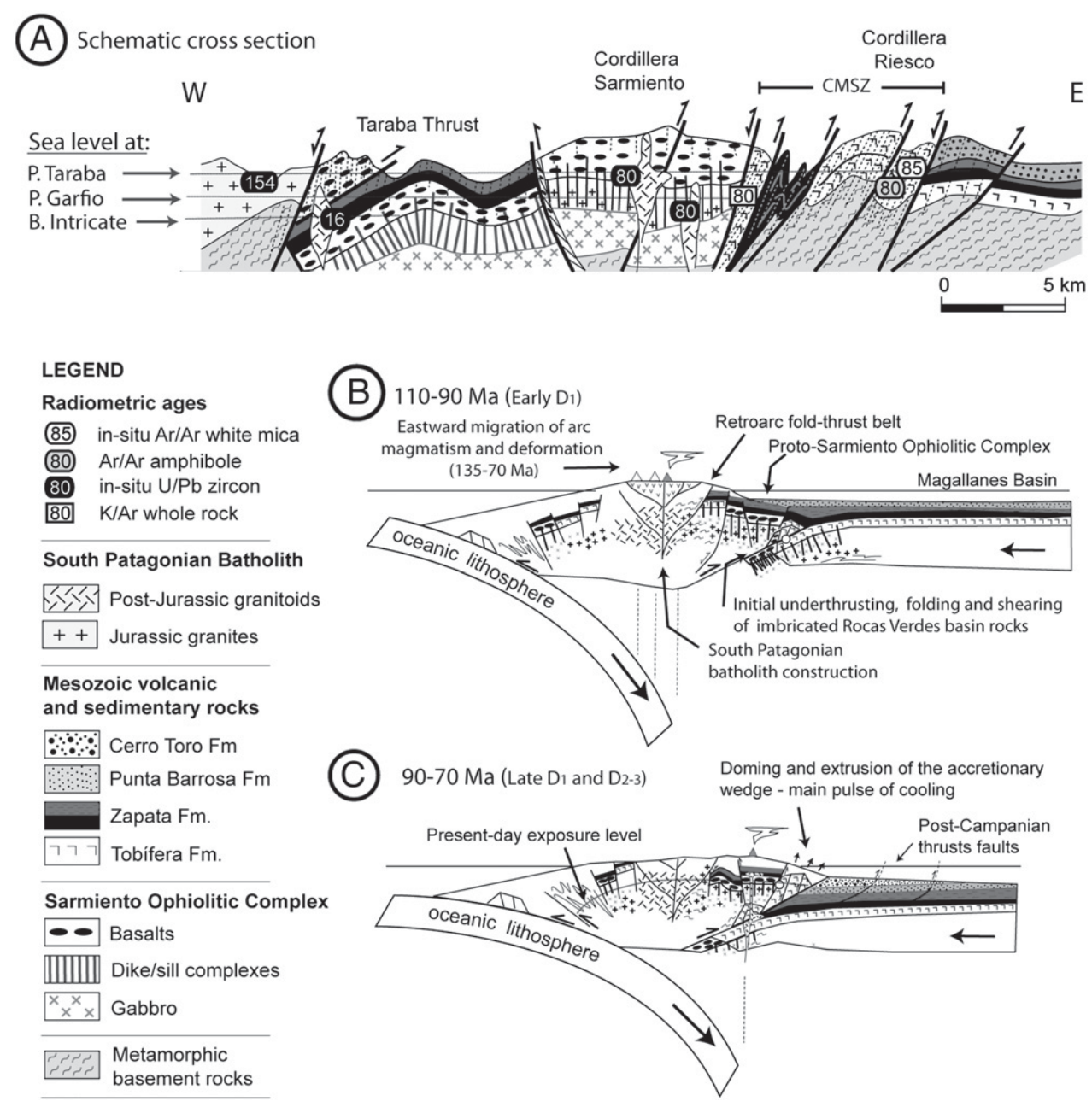

Fig. 10. (A) Schematic E-W geological cross-section of the present-day Patagonian Andes at the latitude of the study area, showing the structural relations between the Cordillera Sarmiento, Canal de Montanas Shear Zone, and the retroforeland region. Paleogeographic reconstructions for (B) 110-90 Ma (C) and 80-70 Ma, based on data and interpretations summarized in the text, indicate the generalized depositional environment of the Rocas Verdes Basin and tectonic emplacement and deformation of the Sarmiento Ophiolitic Complex.

and/or detachment zones developed during subduction and underthrusting can progress during the internal dynamic evolution of the accretionary wedge (cf. Kusky and Bradley, 1999). In addition, the dip of foliations within the CMSZ may have been modified after the post-Campanian event of eastward tilting (Rapalini et al., 2008), likely associated with displacement along deep-seated structures during the latest Cretaceous to Cenozoic time (Fosdick et al., 2011). It is thus envisaged that the present steeply west-dipping to sub-vertical foliations within the CMSZ could have resulted from the overturning of a former less inclined west-dipping foliation. Therefore, while acknowledging the various degrees of uncertainties, geothermobarometric and structural data presented here supports the conjecture of west-directed subduction and continental underthrusting during basin closure. In the general model (Fig. 10), as postulated by Gealey (1980), the SOC is considered to represent the eastern limb of an island arc which collided with the passive continental margin.

\subsection{Timing of deformation and tectonostratigraphic correlations}

The Hauterivian (ca. $130 \mathrm{Ma}$ ) maximum sedimentation age of distal turbiditic successions in the upper member of the folded Zapata Formation at Peninsula Taraba (Fig. 1; Calderón et al., 2007a), constrain the maximum age of $D_{1}$ folding and thrusting deformation and heterogeneous shearing within the CMSZ. Otherwise, the Late Cretaceous $\mathrm{U}-\mathrm{Pb}$ zircon crystallization ages of the plutonic and hypabyssal rocks within the main ophiolitic stack provide a 78-81 Ma upper age limit on the main ophiolite-obduction phase deformation (Fig. 10).

Plutonism within the Sarmiento Complex was concurrent with a regional Late Cretaceous (94-70 Ma) thermal event signalled by an apparent cluster of whole rock $\mathrm{K}-\mathrm{Ar}$ ages from ophiolitic dikes and basalts along the SOC (Rapalini et al., 2008). It seems that $\mathrm{K}-\mathrm{Ar}$ ages constrain, as a first-order approximation, the timing of regional uplift and related cooling of the SOC. Particularly, the 79-82 Ma whole rock $\mathrm{K}$-Ar age on the phyllonite (sample FC0851) is indistinguishable from the age of plutonic rocks (78-81 Ma) located ca.2.5 $\mathrm{km}$ to the east. This sample likely records cooling after the isotopic perturbation of the phyllonite during pluton emplacement at depths of ca. $10 \mathrm{~km}$ or less. Despite this possibility, it is remarkable that the thermal event apparently did not affect the major element composition of minerals which record conditions of low-temperature $\left(230-260^{\circ} \mathrm{C}\right)$ dynamic metamorphism. It is thus apparent that the $\mathrm{K}-\mathrm{Ar}$ whole rock age on phyllonite can be interpreted as the time of recrystallization coeval with plutonism in the area.

The apparent isochron ${ }^{40} \mathrm{Ar} /{ }^{39} \mathrm{Ar}$ age between 84 and $87 \mathrm{Ma}$ obtained from $\mathrm{D}_{1}$-syntectonic phengite (sample ST0402), located ca. $10 \mathrm{~km}$ to the east of the phyllonite band within the CMSZ, is interpreted as representing the time of mica crystallization. This is supported by temperature calculations indicating a maximum temperature of ca. $290{ }^{\circ} \mathrm{C}$, below the closure temperature of the ${ }^{40} \mathrm{Ar} /{ }^{39} \mathrm{Ar}$ isotopic system in white mica (Harrison et al., 2009). In 
the same area, the ${ }^{40} \mathrm{Ar} /{ }^{39} \mathrm{Ar}$ plateau age of $78-80 \mathrm{Ma}$ obtained through step-heating of amphiboles from a post-tectonic lamprophyric dike (sample ST0411) constrains the minimum age of shearing. In addition, this age indicates that dike intrusion was contemporaneous with shallow emplacement of plutonic and hypabyssal porphyritic rocks within the SOC. It is probable that intrusion of postdeformational lamprophyric dikes was synchronous with the late development of the kink bands under brittle conditions.

The ${ }^{40} \mathrm{Ar} /{ }^{39} \mathrm{Ar}$ age data, together with geobarometric considerations that point to a difference of $2 \mathrm{kbar}$ between the pressure of metamorphism along the CMSZ and the pluton emplacement depth within the ophiolitic stack, suggest that between ca. 85 and $80 \mathrm{Ma}$ fast uplift rates of ca. 1-2 mm/yr prevailed during progressive thrust sheet imbrications $\left(D_{1}\right)$ and subsequent doming and back folding $\left(D_{2}\right)$ of the accretionary wedge. Major plate reorganization and changes in global convergence rates can be invoked, but it is thought that the rapid wedge evolution and extrusion, and final juxtaposition of the SOC against the CMSZ was likely associated with the arrival of the (more buoyant) continental crust at the site of subduction (Fig. 10c).

Exhumation and inferred deformation of the SOC and CMSZ domains at this time is consistent with the geologic history of the subsiding Magallanes foreland basin, where coarse clastic sedimentation derived from these units records the presence and evolution of an emergent fold-thrust belt to the west (Fig. 10b; Fildani and Hessler, 2005; Fosdick et al., 2011). Prior to pluton emplacement, the imbricate thrust sheet system of the CMSZ were exhumed ca. $8 \mathrm{~km}$ via uplift and erosion; this eroded cover near the arc orogen was an important source of detritus for the deep-water turbidites (Punta Barrosa and Cerro Toro formations) deposited in the sediment-starved foredeep of the Magallanes basin (Fig. 10c; Galaz et al., 2005; Romans et al., 2009; Wilson, 1991).

\section{Conclusions}

The petrological study of the CMSZ and the identification of the metamorphic sole of the SOC provide insights into the tectonic processes and ultimate fate of quasi-oceanic basins developed by processes of rifting and/or seafloor spreading at convergent margins. Regardless of the possible global causes for the opening and closure of the Rocas Verdes basin, the tectonic emplacement of the SOC resulted in different generations of shear zones and folds associated with several thrusting deformation events. In particular the CMSZ records continentward reverse sense of shearing and thermobarometric constraints indicate its evolution at shallow depths in a subduction zone setting. Although the age of subduction inception within the Rocas Verdes basin is still a matter of study, combined zircon $\mathrm{U}-\mathrm{Pb}$ and phengite ${ }^{40} \mathrm{Ar} /{ }^{39} \mathrm{Ar}$ age data reveal that the main ophiolitic obduction phase and juxtaposition of the SOC and the CMSZ occurred before ca. $80 \mathrm{Ma}$.

\section{Acknowledgements}

This work was supported by Initiation Fondecyt grant 11075000 to M.C., and the international collaboration grants of the GRICESCONICYT (José Munhá and M.C.) and the BMBF-CONICYT (H.-J.M. and F.H) programs. This research paper is a contribution of Anillo Project ACT-105 of CONICYT and PBCYT. Field trips were undertaken in the yatchs Penguin, Foam and Morgane, with captains, Conrado Álvarez (father), Conrado Álvarez (son) and Gilles Rigaud, respectively. We are grateful to many colleagues and seamen who participated and helped during different field campaigns. Thomas Theye, Simon Kelley and Artur Onoe supported the electron microprobe and the ${ }^{40} \mathrm{Ar} /{ }^{39} \mathrm{Ar}$ and $\mathrm{K}-\mathrm{Ar}$ laboratory work, respectively. We acknowledge Ian Dalziel for his insightful reviews and proposed interpretations.

\section{References}

Allen, R.B., 1982. Geología de la Cordillera Sarmiento, Andes Patagónicos, entre los 5100’ y $52^{2} 15$ ' Lat. S, Magallanes, Chile. Servicio Nacional de Geología y Minería. Boletín 38, 1-46. Amaral, G., Cordani, U.G., Kawashita, K., Reynolds, J.H., 1966. Potassium-argon dating of basaltic rocks from Southern Brazil. Geochimimica Cosmochimica Acta 30, 159-189.

Anguita, N., 2010. Petrogénesis de diques lamprofídicos postectónicos y su relación con el magmatismo shoshonítico Cretácico de la Formación Barros Arana y el Complejo La Pera, Magallanes, XII Región, Chile. Unpublished Graduation Thesis, Universidad de Chile, p.237.

Anonymous, 1972. Penrose field conference on ophiolites. Geotimes 17, 24-25.

Aoki, K., Itaya, T., Shibuya, T., Masago, H., Kon, Y., Terabayashi, M., Kaneko, Y., Kawai, T., Maruyama, S., 2008. The youngest blueschist belt in SW Japan: implications for the exhumation of the Cretaceous Sanbagawa high-P/T metamorphic belt. Journal of Metamorphic Geology 26, 583-602.

Avendaño, V., Calderón, M., Hervé, F., Simonetti, A., 2008. Aptian seafloor metamorphic event in the Rocas Verdes basin: titanite U-Pb dating of microbial-like structures in the Tortuga Ophiolite, Fuegian Andes. 33rd International Geological Congress, Symposium MRD-14 Ophiolites. greenstone belts and ore deposits, Oslo, Norway.

Bebout, G.E., Barton, M.D., 1989. Fluid flow and metasomatism in a subduction zone hydrothermal system: Catalina schist terrane, California. Geology 17, 976-980.

Beccaluva, L., Coltorti, M., Giunta, G., Siena, F., 2004. Thethyan vs. Cordilleran ophiolites: a reappraisal of distinctive tectono-magmatic features of supra-subduction complexes in relation to the subduction mode. Tectonophysics 391, 163-174.

Biddle, K.T., Uliana, M.A., Mitchum Jr., R.M., Fitzgerald, M.G., Wright, R.C., 1986. The stratigraphic and structural evolution of the central and eastern Magallanes Basin, southern South America. In: Allen, P.A., Homewood, P. (Eds.), Foreland Basins. : International Association of Sedimentologists Special Publications. Blackwell, Oxford, United Kingdom, pp. 41-63.

Brandelik, A., 2009. CALCMIN - an EXCEL TM Visual Basic application for calculating mineral structural formulae from electron microprobe analyses Source. Computers and Geosciences 35, 1540-1551.

Bruhn, R.L., Stern, C.R., de Wit, M.J., 1978. Field and geochemical data bearing on the development of a Mesozoic volcano-tectonic rift zone and back-arc basin in southernmost South America. Earth and Planetary Science Letters 41, 32-46.

Calderón, M., Galaz, G., Tascón, G., Ramírez, C., Luca, R., Massonne, H.-J., Brandelik, A., Hervé, F., 2005. Metanorphic P-T constraints for non-coaxial ductile flow of Jurassic pyroclastic deposits: key evidence for the closure of the Rocas Verdes basin in southern Chile. 6th International Symposium on Andean Geodynamics. ISAG, Barcelona, pp. 138-141. extended abstracts:.

Calderón, M., Fildani, A., Herve, F., Fanning, C.M., Weislogel, A., Cordani, U., 2007a. Late Jurassic bimodal magmatism in the northern sea-floor remnant of the Rocas Verdes basin, southern Patagonian Andes. Journal of the Geological Society of London 162, 1011-1022.

Calderón, M., Hervé, F., Cordani, U., Massonne, H.-J., 2007b. Crust-mantle interactions and generation of silicic melts: insights from the Sarmiento Complex, southern Patagonian Andes. Revista Geológica de Chile 43 (2), 249-275.

Calderón, M., Fosdick, J., Alvarez, J., Sanchez, A., Galaz, G., 2009. Doubly-vergent structures in metamorphic rocks that enclose the Sarmiento Ophiolite Complex at Senos Lolos and Encuentros, Southern Patagonian Andes (51-52 ${ }^{\circ} \mathrm{S}$ ). XII Congreso Geológico Chileno.

Connolly, J.A.D., 1990. Multivariable phase diagrams; an algorithm based on generalized thermodynamics. American Journal of Science 290, 666-718.

Connolly, J.A.D., 2005. Computation of phase equilibria by linear programming: A tool for geodynamic modeling and its application to subduction zone decarbonation. Earth and Planetary Science Letters 236, 524-541.

Cunningham, W.D., 1995. Orogenesis at the southern tip of the Americas: The structural evolution of the Cordillera Darwin Metamorphic Complex, southernmost Chile. Tectonophysics 244, 197-229.

Curtis, M.L., Flowerdew, M.J., Riley, T.R., Whitehouse, M.J., Stephen, D.J., 2010. Andean sinistral transpression and kinematic partitioning in South Georgia. Journal of Structural Geology 32 (4), 464-477.

Dalziel, I.W.D., 1981. Back-arc extension in the southern Andes: A review and critical reappraisal. Royal Society of London Philosophical Transactions A (300), 319-335.

Dalziel, I.W.D., 1986. Collision and Cordilleran orogenesis. In: Coward, M.P., Ries, A.C. (Eds.), Collision tectonics: Geological Society of London Special Publication, 19, pp. 389-404.

Dalziel, I.W.D., Cortés, R., 1972. Tectonic style of the southernmost Andes and the Antarctandes. XXIV International Geological Congress section 3, 316-327.

Dalziel, I.W.D., de Wit, M.J., Palmer, F., 1974. Fossil marginal basin in the southern Andes. Nature 250, 291-294 London.

de Wit, M.J., Stern, C.R., 1981. Variation in the degree of crustal extension during formation of a back-arc basin. Tectonophysics 72, 229-260.

Dilek, Y., 2003. Ophiolite pulses, mantle plumes and orogeny. Ophiolites in In: Dilek, Y., Robinson, P.T. (Eds.), Ophiolites in Earth History: Geological Society, London, Special Publications, 218, pp. 9-19.

Elthon, D., Stern, C.R., 1978. Metamorphic petrology of the Sarmiento Ophiolite Complex, Chile. Geology 6, 464-468.

Fildani, A., Hessler, A.M., 2005. Stratigraphic record across a retroarc basin inversion: Rocas Verdes-Magallanes basin, Patagonian Andes, Chile. Geological Society of America Bulletin 117, 1596-1614.

Fildani, A., Cope, T.D., Graham, S.A., Wooden, J.L., 2003. Initiation of the Magallanes foreland basin: Timing of the southernmost Patagonian Andes orogeny revised by detrital zircon provenance analysis. Geology 31, 1081-1084.

Forsythe, R., Allen, R.B., 1980. The basement rocks of Península Staines, Región XII, Province of Última Esperanza, Chile. Revista Geológica de Chile 10, 3-15. 
Fosdick, J., Romans, B., Fildani, A., Bernhardt, A., Calderón, M., Graham, S.A., 2011. Kinematic evolution of the Patagonian retroarc fold-thrust belt and Magallanes foreland basin, Chile and Argentina, $51^{\circ} 30^{\prime}$ S. Geological Society of America Bulletin 123 (9/10), 1679-1698.

Fuenzalida, R., Covacevich, V., 1988. Volcanismo y bioestratigrafía del Jurásico y Cretácico Inferior en la Cordillera Patagónica, Región de Magallanes, Chile. In V Congreso Geológico Chileno 3, H159-H183.

Galaz, G., Hervé, F., Calderón, M., 2005. Metamorfismo y deformación de la Formación Tobífera en la Cordillera Riesco, Región de Magallanes, Chile. Revista de la Asociación Geológica Argentina 60 (4), 762-774.

Gealey, W.K., 1980. Ophiolite obduction mechanism. In: Panayiotou, A. (Ed.), Ophiolites. Proceedings International Ophiolite Symposium, Cyprus. Cyprus Geological Survey, Nicosia, pp. 228-243.

Harambour, S., 2002. Deep seated thrusts in the frontal part of the Magallanes fold and thrust belt, Ultima Esperanza, Chile. XV Congreso Geológico Argentino, 3. E Calafate, Argentina, p. 230. CD ROM.

Harrison, T.M., Célérier, J., Aikman, A.B., Hermann, J., Heizler, M.T., 2009. Diffusion of ${ }^{40} \mathrm{Ar}$ in muscovite. Geochimica et Cosmochimica Acta 73 (4), 1039-1051.

Hervé, F., Fanning, C.M., 2003. Early Cretaceous subduction of continental crust at the Diego de Alamgro archipelago, southern Chile. Episodes 26, 285-289.

Hervé, F., Fanning, C.M., Pankhurst, R.J., 2003. Detrital zircon age patterns and provenance of the metamorphic complexes of southern Chile. Journal of South American Earth Sciences 16, 107-123.

Hervé, F., Massonne, H.-J., Calderón, M., Theye, T., 2007a. Metamorphic P-T conditions of Late Jurassic rhyolites in the Magallanes fold and thrust belt, Patagonian Andes, Chile. Journal of Iberian Geology 33, 5-16.

Hervé, F., Pankhurst, R.J., Fanning, C.M., Calderón, M., Yaxley, G.M., 2007b. The South Patagonian batholith: 150 my of granite magmatism on a plate margin. Lithos 97, 373-394

Holland, T.J.B., Powell, R., 1998. An internally consistent thermodynamic data set fo phases of petrological interest. Journal of Metamorphic Geology 16, 309-343.

Katz, H.R., 1964. Some new concepts on geosynclinal development and mountain building at the southern end of South America. 22nd International Geological Congress, India, Proceedings. New Delhi 4, 242-255.

Klepeis, K., Betka, P., Clarke, G., Fanning, M., Hervé, F., Rojas, L., Mpodozis, C., Thomson, S.N., 2010. Continental underthrusting and obduction during the Cretaceous closure of the Rocas Verdes rift basin, Cordillera Darwin, Patagonian Andes. Tectonics 29, TC3014. doi:10.1029/2009TC002610.

Kohn, M.J., Spear, F.S., Harrison, T.M., Dalziel, I.W.D., 1995. ${ }^{40} \mathrm{Ar} /{ }^{39} \mathrm{Ar}$ geochronology and P-T-t paths from the Cordillera Darwin metamorphic complex, Tierra de Fuego, Chile. Journal of Metamorphic Geolology 13, 251-270.

Kraemer, P.E., 2003. Orogenic shortening and the origin of the Patagonian orocline $\left(56^{\circ}\right.$ S.Lat). Journal of South American Earth Sciences 15, 731-748.

Kusky, T.M., Bradley, D.C., 1999. Kinematic analysis of melange fabrics : examples and applications from the McHugh Complex, Kenai Peninsula, Alaska. Journal of Structural Geology 21, 1773-1796.

Leake, B.E., Woolley, A.R., Arps, C.E.S., Birch, W.D., Gilbert, M.C., Grice, J.D., Hawthorne, C., Kato, A., Kisch, H.J., Krivovichev, V.G., Linthout, K., Laird, J., Mandarino, J.A. Maresch, W.V., Nickel, E.H., Rock, N.M.S., Schumacher, J.C., Smith, D.C., Stephenson, C.N., Ungaretti, L., Whittaker, E.J.W., Youzhi, G., 1997. Nomenclature of amphiboles: report of the subcommittee on amphiboles of the International Mineralogical Association, Commission on new minerals and mineral names. American Mineralogist 82, 1019-1037.

Ludwig, K.R., 2000. SQUID 1.00, A User's Manual; Berkeley Geochronology Center Special Publication, n. 2, p. 2455

Maloney, K.T., Clarke, G.L., Klepeis, K.A., Fanning, C.M., Wang, W., 2011. Crustal growth during back-arc closure: Cretaceous exhumation history of Cordillera Darwin, southern Patagonia. Journal of Metamorphic Geology 29 (6), 649-672.

Mapa Geológico de Chile: version digital. publicación geológica digital, No. 4, 2003. CDROM, versión 1.0, 2003. Base Geológica escala 1:1.000.000. Gobierno de Chile, Servicio Nacional de Geología y Minería, Subdirección Nacional de Geología.

Massonne, H.-J., 2010. Phase relations and dehydration behaviour of calcareous sediments at very-low to low grade metamorphic conditions. Periodico di Mineralogia 79 (2), 21-43.

Massonne, H.-J., Szpurka, Z., 1997. Thermodynamic properties of white micas on the basis of high-pressure experiments in the systems $\mathrm{K}_{2} \mathrm{O}-\mathrm{MgO}-\mathrm{Al}_{2} \mathrm{O}_{3}-\mathrm{SiO}_{2}-\mathrm{H}_{2} \mathrm{O}$ and $\mathrm{K}_{2} \mathrm{O}-\mathrm{FeO}-\mathrm{Al}_{2} \mathrm{O}_{3}-\mathrm{SiO}_{2}-\mathrm{H}_{2} \mathrm{O}$. Lithos 41, 229-250.

Massonne, H.J., Willner, A., 2008. Dehydration behaviour of metapelites and mid-ocean ridge basalt at very-low to low grade metamorphic conditions. European Journal of Mineralogy 20, 867-879.

Massonne, H.J., Willner, A., Gerya, T., 2007. Densities of metapelitic rocks at high to ultrahigh pressure conditions: what are the geodynamic consequences? Earth and Planetary Science Letters 256, 12-27.

Mukasa, S., Dalziel, I.W.D., 1996. Southernmost Andes and South Georgia Island, North Scotia Ridge: zircon U-Pb and muscovite Ar-Ar age constraints on tectonic evolution of southwestern Gondwanaland. Journal of South American Earth Science 9, 349-365.

Natland, M.L., Gonzalez, P.E., Canon, A., Ernst, M., 1974. A system of stages for correlation of Magallanes Basin sediments. American Association of Petroleum Geologists Memoir 139126 pp.

Pankhurst, R.J., Riley, T.R., Fanning, C.M., Kelley, S.P., 2000. Episodic silicic volcanism in Patagonia and the Antarctic Peninsula: Chronology of magmatism associated with the break-up of Gondwana. Journal of Petrology 41, 603-625.

Pearce, J.A., Lippard, S.J., Roberts, S., 1984. Characteristics and tectonic significance of supra-subduction zone ophiolites. In: Kokelaar, B.P., Howells, M.F. (Eds.), Marginal Basin Geology: Volcanic and Associated Sedimentary and Tectonic Processes in
Modern and Ancient Marginal Basins: Geological Society, London, Special Publications, 16, pp. 77-96.

Powell, R., Holland, T., 1999. Relating formulations of the thermodynamics of minera solid solutions: Activity modeling of pyroxenes, amphiboles and micas. American Mineralogist 84, 1-14.

Prieto, X., 1994. Geología regional del sector comprendido entre Seno Última Esperanza y Seno Obstrucción: precordillera de la Región de Magallanes. Unpublished Graduation Thesis, Universidad de Chile, $142 \mathrm{p}$.

Pryer, L.L., 1983. Microstructures in feldspars from a major crustal thrust zone: the Grenville Front, Ontario, Canada. Journal of Structural Geology 15, 21-36.

Ramírez, C., 2006. Ambiente tectónico de emplazamiento de la Formación Barros Arana. Unpublished Graduation Thesis, Universidad de Chile, 117 p.

Rapalini, A.E., Calderón, M., Singer, S., Hervé, F., Cordani, U., 2008. Tectonic implications of a paleomagnetic study of the Sarmiento Ophiolitic Complex, southern Chile. Tectonophysics 452, 29-41.

Renne, P.R., Swisher, C.C., Deino, A.L., Kramer, D.B., Owens, T.L., DePaolo, D.J., 1998. Intercalibration of standards, absolute ages and uncertainities in ${ }^{40} \mathrm{Ar} /{ }^{39} \mathrm{Ar}$ dating. Chemical Geology 145, 117-152.

Romans, B.W., Fildani, A., Graham, S.A., Hubbard, S.M., Covault, J.A., 2009. Importance of predecessor basin history on sedimentary fill of a retroarc foreland basin: provenance analysis of the Cretaceous Magallanes basin, Chile (50 52 'S). Basin Research. doi:10.1111/j.1365-2117.2009.00443.x

Rutter, E.H., 1983. Pressure solution in nature, theory and experiment. Journal of the Geological Society of London 140, 725-740.

Saunders, A.D., Tarney, J., Stern, C.R., Dalziel, I.W.D., 1979. Geochemistry of Mesozoic marginal basin floor igneous rocks from southern Chile. Geological Society Bulletin of America 90, 237-258.

Schmidt, M.W., 1992. Amphibole composition in tonalite as a function of pressure: an experimental calibration of the $\mathrm{Al}$-in-hornblende barometer. Contributions to Mineralogy and Petrology 110, 304-310.

Steiger, R.H., Jaeger, E., 1977. Subcommission on geochronology: convention on the use of decay constants in age and cosmochronology. Earth and Planetary Science Letters 36 359-362.

Stern, C.R., 1979. Open and closed system igneous fractionation within two Chilean ophiolites and the tectonic implications. Contribution to Mineralogy and Petrology $68,243-258$

Stern, C.R., 1991. Isotopic composition of Late Jurassic and Early Cretaceous mafic igneous rocks from the southernmost Andes: implications for sub-Andean mantle. Revista Geológica de Chile 18, 15-23.

Stern, C.R., de Wit, M.J., 2003. Rocas Verdes ophiolites, southernmost South America: remnants of progressive stages of development on oceanic-type crust in a continental margin back-arc basin. In: Dilek, Y., Robinson, P.T. (Eds.), Ophiolites in Earth History: Geological Society, London, Special Publications, 218, pp. 1-19.

Stern, C.R., de Wit, M.J., Lawrence, J.R., 1976. Igneous and metamorphic processes associated with the formation of Chilean ophiolites and their implications for ocean floor metamorphism, seismic layering, and magnetism. Journal of Geophysical Research 81 (23), 4370-4380

Stern, C.R., Mohseni, P.P., Fuenzalida, R., 1991. Petrochemistry and tectonic significance of Lower Cretaceous Barros Arana Formation basalts, southernmost Chilean Andes. Journal of South American Earth Sciences 4 (4), 331-342.

Stewart, J., Cruzat, A., Page, B., Suárez, M., Stambuk, V., 1971. Estudio geológico eco-

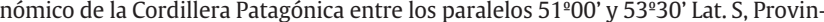
cia de Magallanes. Instituto de Investigación Geológica, unpublished, 174 p.

Storey, B.C., Mair, B.F., 1982. The composite floor of the Cretaceous back-arc basin of South Georgia. Journal of the Geological Society of London 139, 729-737.

Suárez, M., Pettigrew, T.H., 1976. An Upper Mesozoic island-arc-back-arc system in the southern Andes and South Georgia. Geological Magazine 113, 305-328.

Tera, F., Wasserburg, G., 1972. U-Th-Pb systematics in three Apollo 14 basalts and the problem of initial $\mathrm{Pb}$ in lunar rocks. Earth and Planetary Science Letters 14, 281-304.

Tullis, J., Yund, R., Farver, J., 1996. Deformation-enhanced fluid distribution in feldspar aggregates and implications for ductile shear zones. Geology 24, 63-66.

van Staal, C.R., Rogers, N., Taylor, B.E., 2001. Formation of low-temperature mylonites and phyllonites by alkali-metasomatic weakening of felsic volcanic rocks during progressive, subduction-related deformation. Journal of Structural Geology 23, 903-921.

Wakabayashi, J., Dilek, Y., 2003. What constitutes 'emplacement' of an ophiolite? Mechanism and relationship tp subduction initiation and formation of metamorphic soles. Ophiolites in In: Dilek, Y., Robinson, P.T. (Eds.), Ophiolites in Earth History: Geological Society, London, Special Publications, 218, pp. 427-447.

White, J.C., White, S.H., 1981. On the structure of grain boundaries in tectonites. Tectonophysics $78,613-628$.

Williams, I.S., 1998. U-Th-Pb geochronology by ion microprobe. In: McKibben, M.A. Shanks III, W.C., Ridley, W.I. (Eds.), Applications of Microanalytical Techniques to Understanding Mineralizing Processes: Reviews in Economic Geology, 107, pp. $1-35$.

Willner, A.P., Hervé, F., Thomson, S.N., Massonne, H.-J., 2004. Converging PT-paths of Mesozoic HP-LT metamorphic units (Diego de Almagro Island, Southern Chile $51^{\circ} 30 \mathrm{pS}$ ): Evidence for juxtaposition during late shortening of an active continental margin. Mineralogy and Petrology 81, 43-84.

Wilson, T.J., 1991. Transition from back-arc to foreland basin development in southernmost Andes: Stratigraphic record from the Ultima Esperanza District, Chile. Geological Society of America Bulletin 103, 98-111.

Wintsch, R.P., Christoffersen, R., Kronenberg, A.K., 1995. Fluid-rock reaction weakening of fault zones. Journal of Geophysical Research 100, 13021-13032. 